\title{
LEVEL II SCOUR ANALYSIS FOR BRIDGE 33 (CASTTH00050033) on TOWN HIGHWAY 5, crossing the CASTLETON RIVER, CASTLETON, VERMONT
}

Open-File Report 98-542

Prepared in cooperation with

VERMONT AGENCY OF TRANSPORTATION

and

FEDERAL HIGHWAY ADMINISTRATION

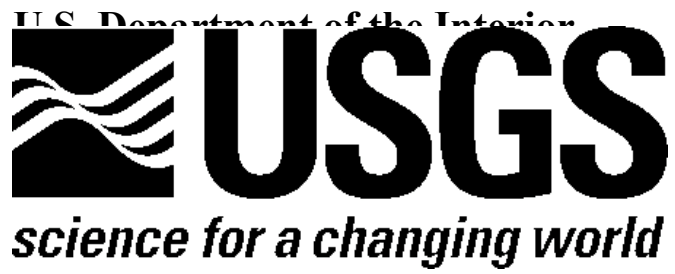




\section{LEVEL II SCOUR ANALYSIS FOR BRIDGE 33 (CASTTH00050033) on TOWN HIGHWAY 5, crossing the CASTLETON RIVER, CASTLETON, VERMONT}

By ERICK M. BOEHMLER AND TIMOTHY SEVERANCE

U.S. Geological Survey Open-File Report 98-542

Prepared in cooperation with

VERMONT AGENCY OF TRANSPORTATION

and

FEDERAL HIGHWAY ADMINISTRATION 


\title{
U.S. DEPARTMENT OF THE INTERIOR BRUCE BABBITT, Secretary
}

\author{
U.S. GEOLOGICAL SURVEY
}

Thomas J. Casadevall, Acting Director

For additional information write to:

District Chief

U.S. Geological Survey 361 Commerce Way

Pembroke, NH 03275-3718
Copies of this report may be purchased from:

U.S. Geological Survey

Branch of Information Services

Open-File Reports Unit

Box 25286

Denver, CO 80225-0286 


\section{CONTENTS}

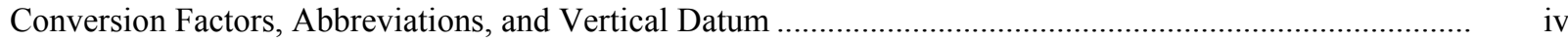

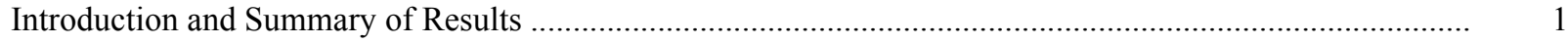

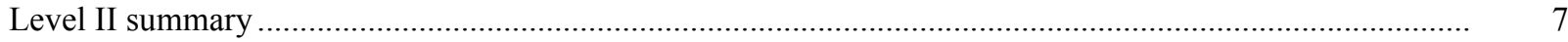

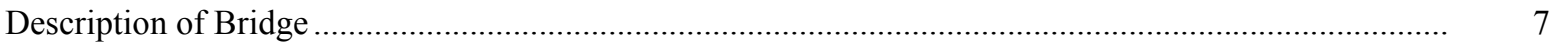

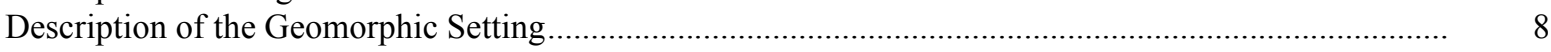

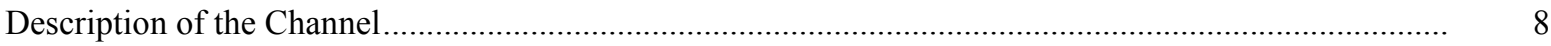

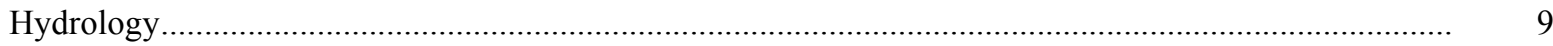

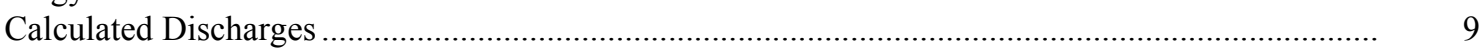

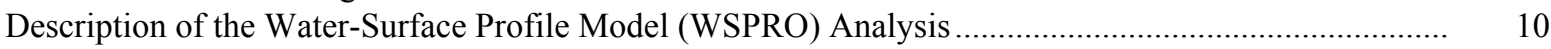

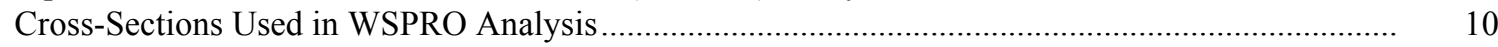

Data and Assumptions Used in WSPRO Model ........................................................................ 11

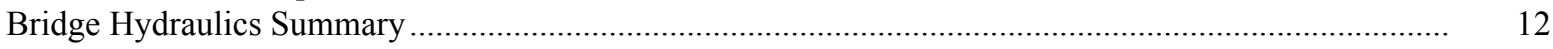

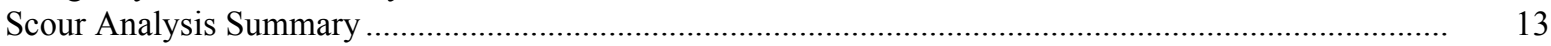

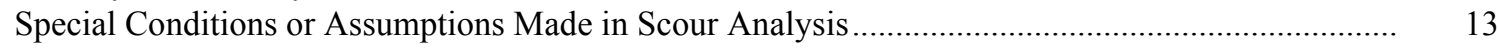

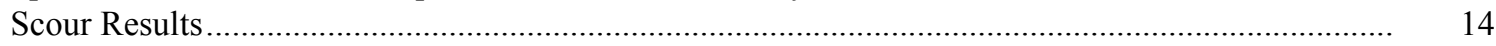

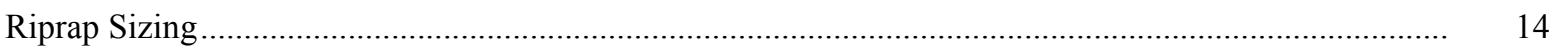

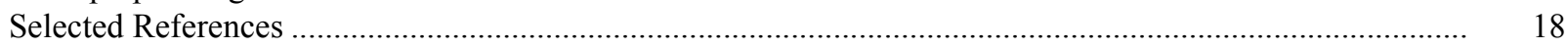

Appendices:

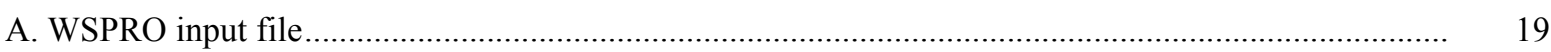

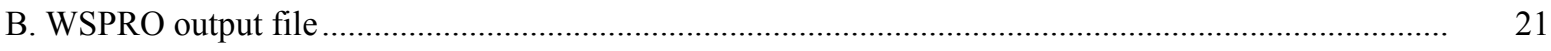

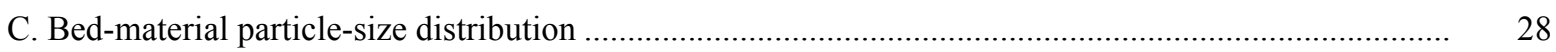

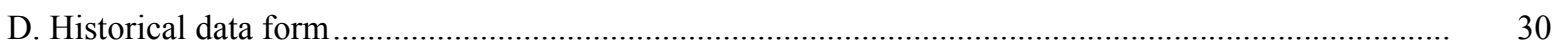

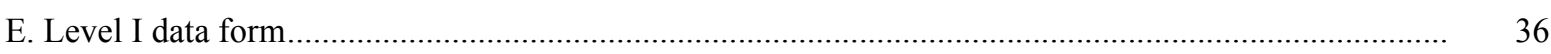

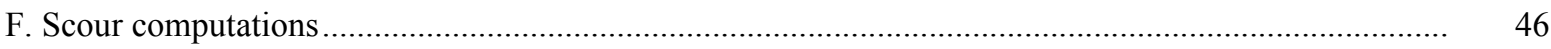

\section{FIGURES}

1. Map showing location of study area on USGS 1:24,000 scale map

2. Map showing location of study area on Vermont Agency of Transportation town highway map

3. Structure CASTTH00050033 viewed from upstream (September 20, 1995)....

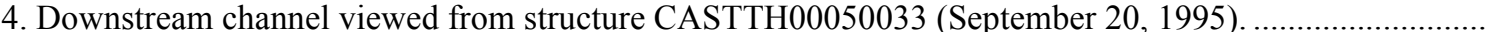

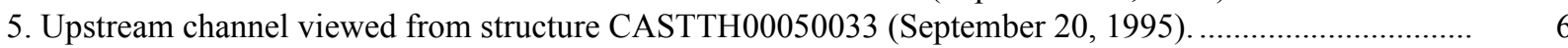

6. Structure CASTTH00050033 viewed from downstream (September 20, 1995).

7. Water-surface profiles for the 100- and 500-year discharges at structure

CASTTH00050033 on Town Highway 5, crossing the Castleton River,

Castleton, Vermont.

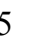
6

8. Scour elevations for the 100 - and 500-year discharges at structure

CASTTH00050033 on Town Highway 5, crossing the Castleton River, Castleton, Vermont.

\section{TABLES}

1. Remaining footing/pile depth at abutments for the 100-year discharge at structure CASTTH00050033 on Town Highway 5, crossing the Castleton River, Castleton, Vermont

2. Remaining footing/pile depth at abutments for the 500-year discharge at structure

CASTTH00050033 on Town Highway 5, crossing the Castleton River,

Castleton, Vermont 


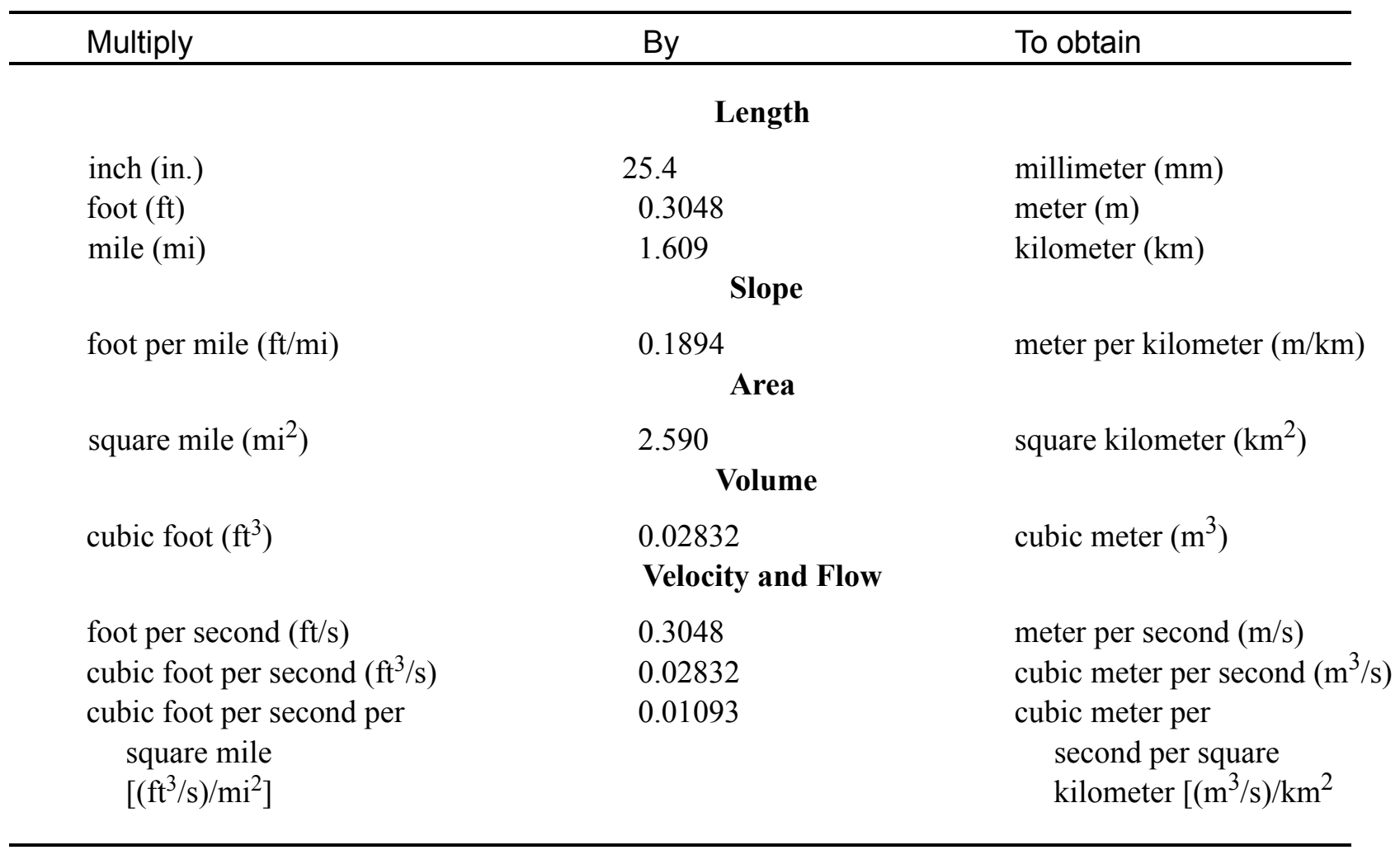

\section{OTHER ABBREVIATIONS}

$\begin{array}{lrlr}\mathrm{BF} & \text { bank full } & \text { LWW } & \text { left wingwall } \\ \mathrm{cfs} & \text { cubic feet per second } & \text { Max } & \text { maximum } \\ \mathrm{D}_{50} & \text { median diameter of bed material } & \text { MC } & \text { main channel } \\ \mathrm{DS} & \text { downstream } & \text { RAB } & \text { right abutment } \\ \mathrm{elev} & \text { elevation } & \text { RABUT } & \text { face of right abutment } \\ \mathrm{f} / \mathrm{p} & \text { flood plain } & \text { RB } & \text { right bank } \\ \mathrm{ft} & \text { square feet } & \text { ROB } & \text { right overbank } \\ \mathrm{ft} / \mathrm{ft} & \text { feet per foot } & \text { RWW } & \text { right wingwall } \\ \mathrm{FEMA} & \text { Federal Emergency Management Agency } & \text { TH } & \text { town highway } \\ \mathrm{FHWA} & \text { Federal Highway Administration } & \text { UB } & \text { under bridge } \\ \mathrm{JCT} & \text { junction } & \text { US } & \text { upstream } \\ \text { LAB } & \text { left abutment } & \text { USGS } & \text { United States Geological Survey } \\ \text { LABUT } & \text { face of left abutment } & \text { VTAOT } & \text { Vermont Agency of Transportation } \\ \text { LB } & \text { left bank } & \text { WSPRO } & \text { water-surface profile model } \\ \text { LOB } & \text { left overbank } & \text { yr } & \text { year }\end{array}$

In this report, the words "right" and "left" refer to directions that would be reported by an observer facing downstream. Sea level: In this report, "sea level" refers to the National Geodetic Vertical Datum of 1929-- a geodetic datum derived from a general adjustment of the first-order level nets of the United States and Canada, formerly called Sea Level Datum of 1929.

In the appendices, the above abbreviations may be combined. For example, USLB would represent upstream left bank. 


\title{
LEVEL II SCOUR ANALYSIS FOR BRIDGE 33 (CASTTH00050033) ON TOWN HIGHWAY 5, CROSSING THE CASTLETON RIVER, CASTLETON, VERMONT
}

\author{
By Erick M. Boehmler and Timothy Severance
}

\section{INTRODUCTION AND SUMMARY OF RESULTS}

This report provides the results of a detailed Level II analysis of scour potential at structure CASTTH00050033 on Town Highway 5 crossing the Castleton River, Castleton, Vermont (figures 1-8). A Level II study is a basic engineering analysis of the site, including a quantitative analysis of stream stability and scour (FHWA, 1993). Results of a Level I scour investigation also are included in appendix $\mathrm{E}$ of this report. A Level I investigation provides a qualitative geomorphic characterization of the study site. Information on the bridge, gleaned from Vermont Agency of Transportation (VTAOT) files, was compiled prior to conducting Level I and Level II analyses and is found in appendix D.

The site is in the Champlain section of the St. Lawrence Valley physiographic province in west-central Vermont. However, the majority of the drainage area is occupied in the Taconic section of the New England province. The 36.9- $\mathrm{mi}^{2}$ drainage area is in a predominantly rural and forested basin. In the vicinity of the study site, the setting is suburban. Surface cover consists of shrubs and brush with a railroad, a residential roadway, and a house with a grass lawn along the left bank. The right bank upstream is a grass lawn bordering a cemetery and is categorized as pasture. The right bank downstream surface cover is forest.

In the study area, the Castleton River has a sinuous channel with a slope of approximately $0.003 \mathrm{ft} / \mathrm{ft}$, an average channel top width of $76 \mathrm{ft}$ and an average bank height of $9 \mathrm{ft}$. The channel bed material ranges from silt and clay to cobbles with a median grain size $\left(\mathrm{D}_{50}\right)$ of $19.4 \mathrm{~mm}(0.064 \mathrm{ft})$. The geomorphic assessment at the time of the Level I and Level II site visit on September 20, 1995, indicated that the reach was stable.

The Town Highway 5 crossing of the Castleton River is a 41-ft-long, one-lane bridge consisting of one 37-foot steel-beam span (Vermont Agency of Transportation, written communication, March 20,1995). The opening length of the structure parallel to the bridge face is $34 \mathrm{ft}$. The bridge is supported by vertical, concrete abutments with wingwalls. The channel is skewed approximately 40 degrees to the opening while the opening-skew-toroadway is zero degrees. 
A scour hole $2.5 \mathrm{ft}$ deeper than the mean thalweg depth was observed in the center of the channel under the bridge and up to 0.75 feet of scour was observed along the right abutment and the upstream right wingwall during the Level I assessment. The scour protection measure at the site included type-1 (less than 12 inches diameter), type-2 (less than 36 inches diameter) and type-3 (less than 48 inches diameter) stone fill. The type- 1 stone fill was observed on the abutments and the upstream right wingwall. Type- 2 stone fill was observed on the upstream right bank and the upstream left wingwall. Type- 3 stone fill was observed along both banks downstream. Additional details describing conditions at the site are included in the Level II Summary and appendices D and E.

Scour depths and recommended rock rip-rap sizes were computed using the general guidelines described in Hydraulic Engineering Circular 18 (Richardson and Davis, 1995) for the 100- and 500-year discharges. In addition, the incipient roadway-overtopping discharge was determined and analyzed as another potential worst-case scour scenario. Total scour at a highway crossing is comprised of three components: 1) long-term streambed degradation; 2) contraction scour (due to accelerated flow caused by a reduction in flow area at a bridge) and; 3 ) local scour (caused by accelerated flow around piers and abutments). Total scour is the sum of the three components. Equations are available to compute depths for contraction and local scour and a summary of the results of these computations follows.

Contraction scour for all modelled flows ranged from 0.7 to $7.0 \mathrm{ft}$. The worst-case contraction scour occurred at the 500-year discharge. Abutment scour ranged from 14.9 to $20.1 \mathrm{ft}$. The worst-case abutment scour occurred at the 500-year discharge. Additional information on scour depths and depths to armoring are included in the section titled "Scour Results". Scoured-streambed elevations, based on the calculated scour depths, are presented in tables 1 and 2. A cross-section of the scour computed at the bridge is presented in figure 8. Scour depths were calculated assuming an infinite depth of erosive material and a homogeneous particle-size distribution.

It is generally accepted that the Froehlich equation (abutment scour) gives "excessively conservative estimates of scour depths" (Richardson and Davis, 1995, p. 46). Usually, computed scour depths are evaluated in combination with other information including (but not limited to) historical performance during flood events, the geomorphic stability assessment, existing scour protection measures, and the results of the hydraulic analyses. Therefore, scour depths adopted by VTAOT may differ from the computed values documented herein. 


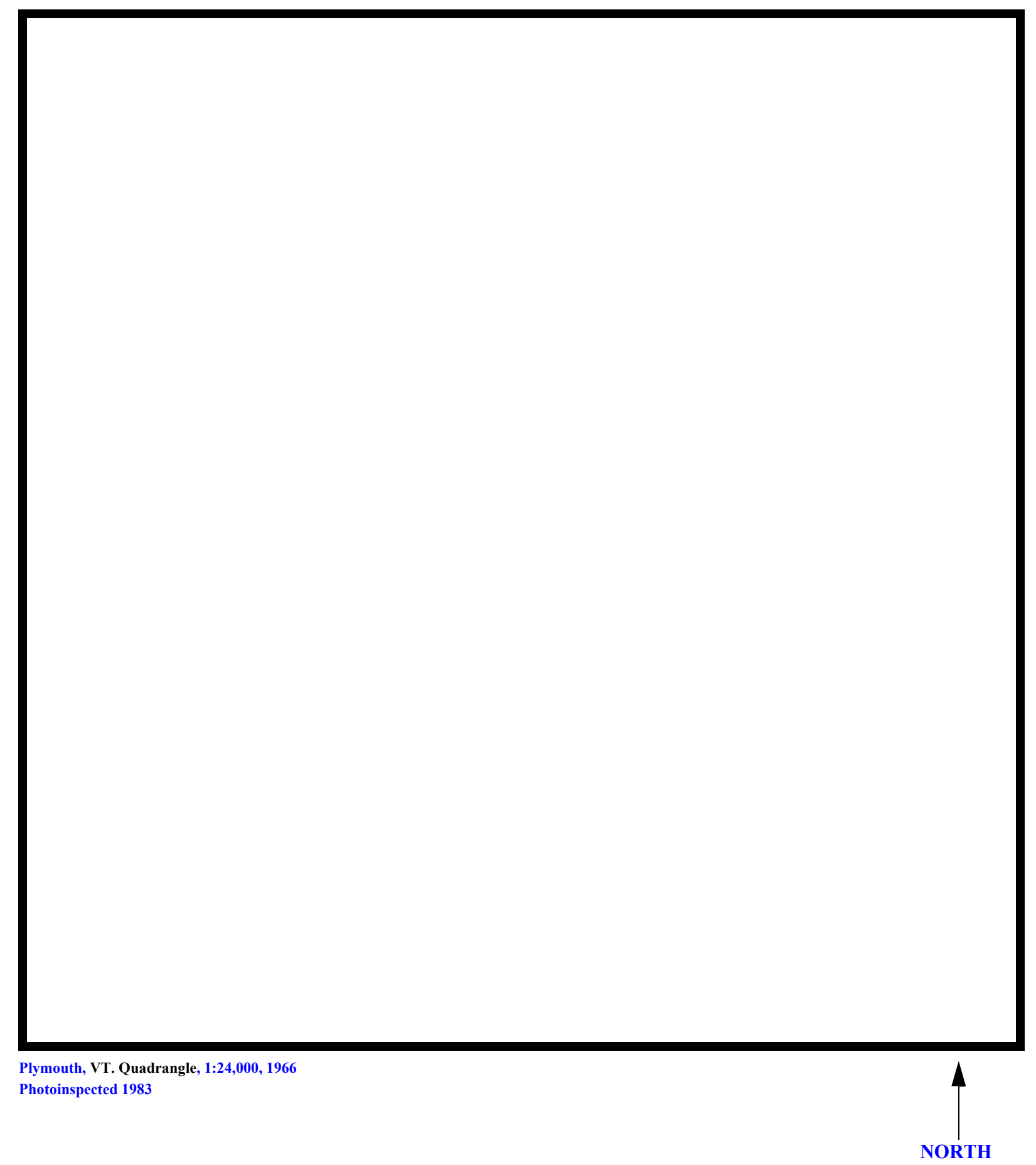

Figure 1. Location of study area on USGS 1:24,000 scale map. 
Figure 2. Location of study area on Vermont Agency of Transportation town highway map. 

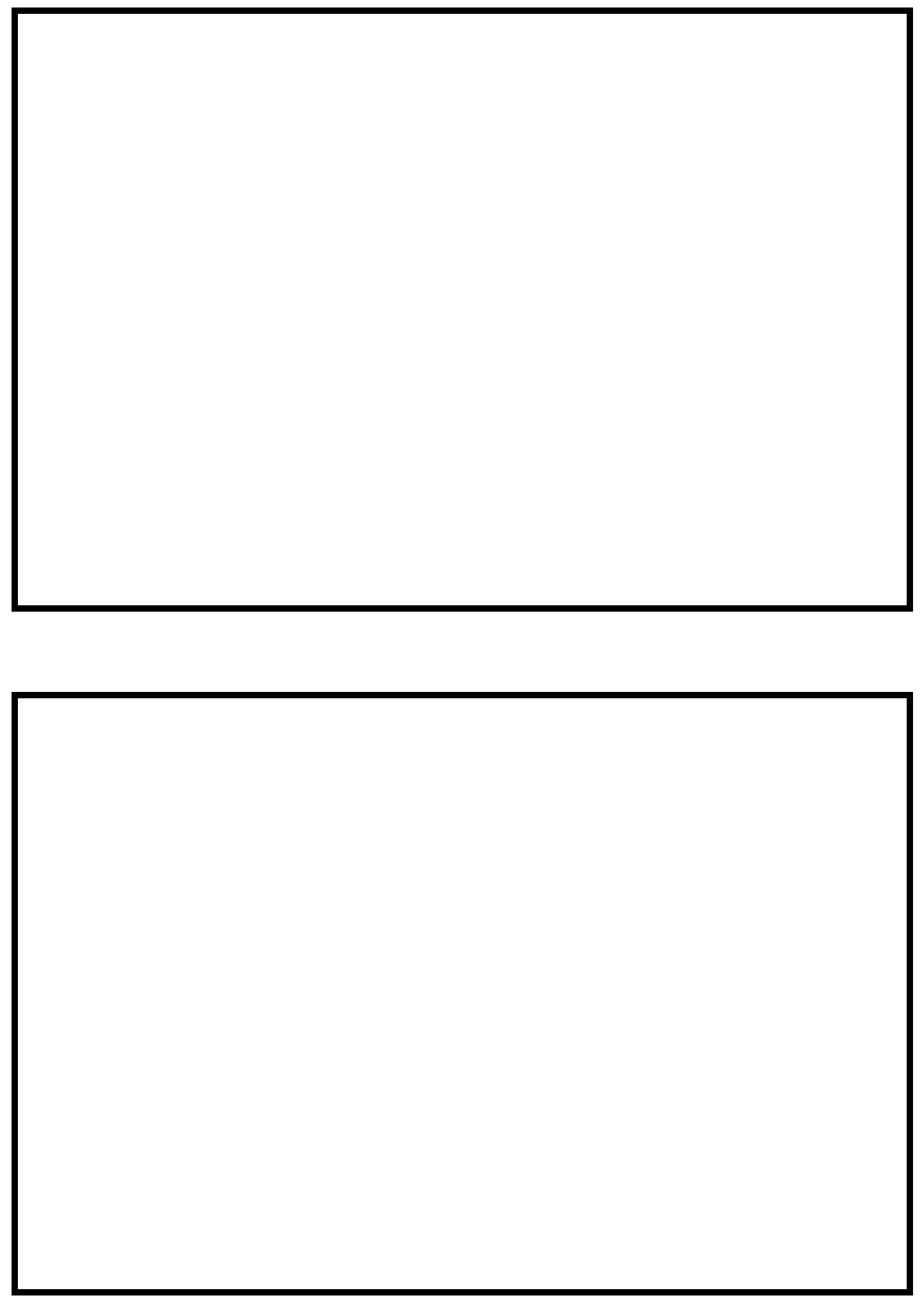

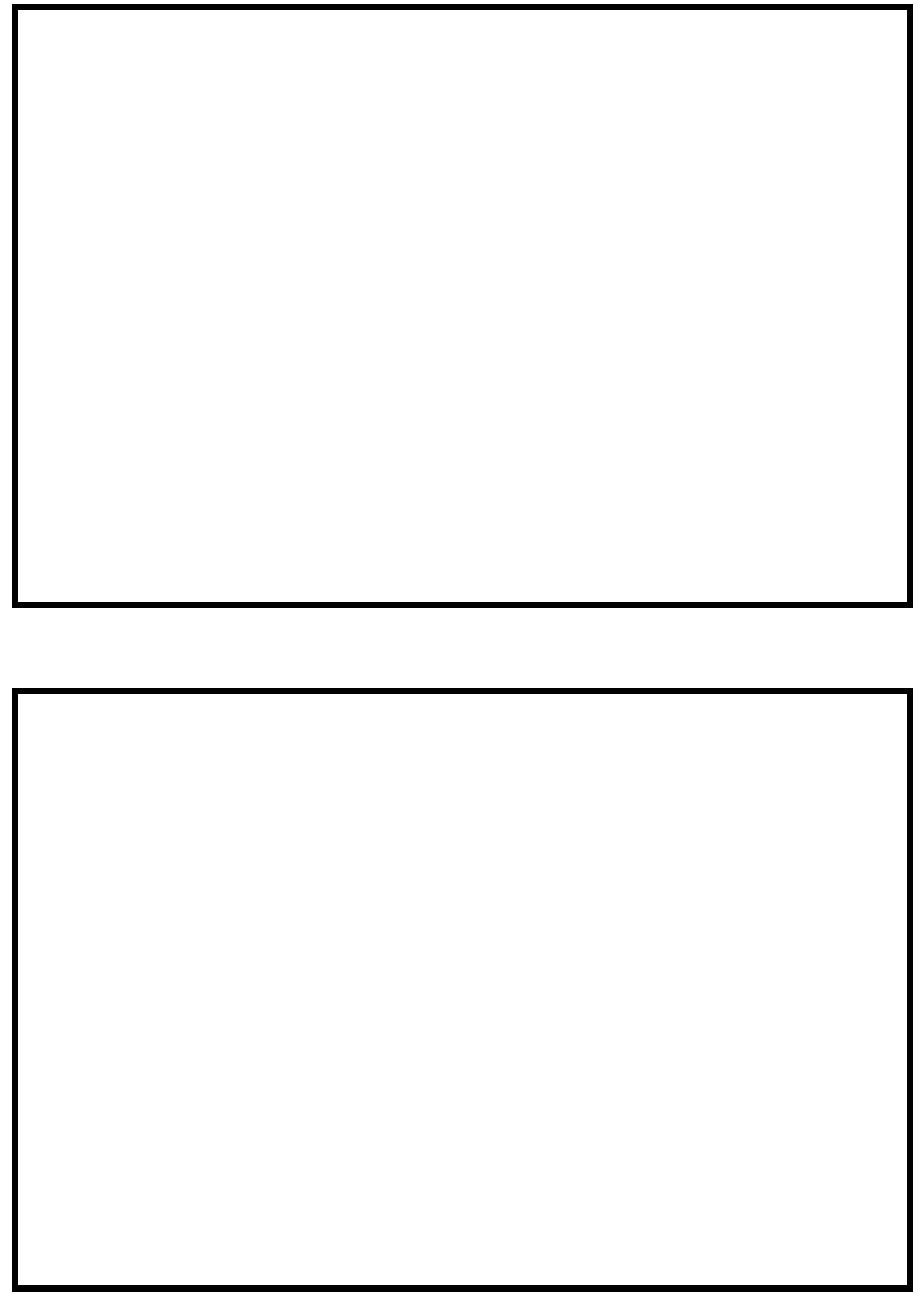


\section{LEVEL II SUMMARY}

\begin{tabular}{|c|c|c|c|c|}
\hline Structure Number & CASTTH00050033 & Stream & Castleton River & \\
\hline Rutl & & & TH 5 & \\
\hline
\end{tabular}

\section{Description of Bridge}

Bridge length $\stackrel{41}{n} \boldsymbol{f t}$ Bridge width $\frac{14.5}{f t}$ Max span length $\frac{37}{\mathrm{ft}}$ Alignment of bridge to road (on curve or straight)

\section{Abutment type} Vertical, concrete

Stone fill on abutment?

$$
\text { Yes }
$$

\section{Embankment type}

Curved right and straight left

Sloping nearly vertical

$$
\text { 9/20/95 }
$$

\section{Dato af incnortion} Type- 1 at the downstream end of the right abutment, the entire base
Dasmintine. af atams fil length of the left abutment, and the upstream end of the upstream right wingwall, and type- 2 along the entire base length of the upstream left wingwall.

The right abutment is concrete and the left abutment is a stone wall. The upstream and downstream right wingwalls are concrete and the upstream left wingwall is a stone wall.

$$
\text { Yes }
$$

Is bridge skewed to flood flow according to Yes ' survey? Angle

There is a moderate channel bend in the upstream reach. A scour hole has developed in the,

\begin{tabular}{|c|c|c|c|}
\hline & $\begin{array}{c}\text { Date of insnortion } \\
9 / 20 / 95 \\
\end{array}$ & $\begin{array}{l}\text { Percent of almmust } \\
\text { blocked inortzontatly }\end{array}$ & $\begin{array}{l}\text { Percent of } 0 \\
\text { blocked verticatty }\end{array}$ \\
\hline & $9 / 20 / 95$ & 0 & 0 \\
\hline & Low. & & \\
\hline
\end{tabular}
location where the bend impacts the upstream right wingwall.

Debris accumulation on bridge at time of Level I or Level II site visit:

\section{Potential for debris}

None were observed on 9/20/95. 


\section{Description of the Geomorphic Setting}

General topography The channel is located in a moderate relief valley, with irregular and narrow over-banks and moderately sloping valley walls on both sides.

Geomorphic conditions at bridge site: downstream (DS), upstream (US)

Date of inspection $\quad 9 / 20 / 95$

DS left: $\quad$ Steep channel bank (railroad embankment) to a flat overbank.

DS right: $\quad$ Steep channel bank to an irregular overbank.

US left: $\quad$ Steep channel bank (railroad embankment) to a flat overbank.

US right: $\quad$ Steep channel bank to an irregular overbank and steep valley wall.

\section{Description of the Channel}

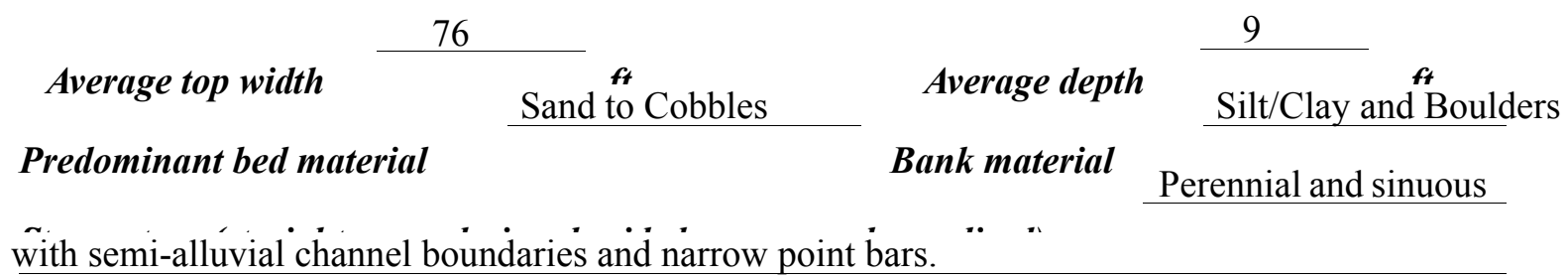

$9 / 20 / 95$

Vegetative co 1 Shrubs, brush and a few trees

DS left: $\quad$ Trees with some shrubs and brush

DS right: $\quad$ Trees, shrubs, and brush

US left: $\quad$ Short grass

US right: $\quad$ Yes

Do banks appear stable? -

date of observatton.

None were observed on

9/20/95.

Describe any obstructions in channel and date of observation. 


\section{Hydrology}

Drainage area $\quad 36.9 \boldsymbol{m i}^{2}$

Percentage of drainage area in physiographic provinces: (approximate)

Physiographic province/section

St. Lawrence Valley / Champlain

New England / Taconic
Percent of drainage area

5

95

Is drainage area considered rural or urban? Rural Describe any significant urbanization:

While the drainage area is rural the site is suburban. A railway, cemetery, and

residential houses are located in the vicinity of the site.

Is there a USGS gage on the stream of interest?

No

USGS gage description
USGS gage number
Gage drainage area

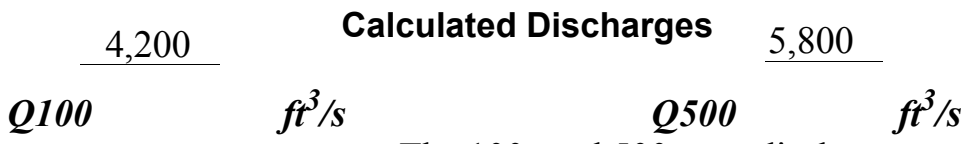

The 100- and 500-year discharges are based on flood

frequency estimates available from the VTAOT database records (written communication, May, 1995) for this site. The VTAOT values were within a range defined by flood frequency curves developed from several empirical methods (Benson, 1962; Johnson and Tasker, 1974; FHWA, 1983; Potter, 1957a\&b; Talbot, 1887). Each curve was extended graphically to the 500-year event. 


\section{Description of the Water-Surface Profile Model (WSPRO) Analysis}

Datum for WSPRO analysis (USGS survey, sea level, VTAOT plans)

USGS survey

Datum tie between USGS survey and VTAOT plans

None. Add 91.9 feet to the USGS'

survey to obtain the National Geodetic Vertical Datum of 1929.

Description of reference marks used to determine USGS datum. $\quad$ RM1 is a National

Geodetic Survey Benchmark engraved "L25" on top of the upstream right wingwall at the upstream end (elev. $497.49 \mathrm{ft}$, arbitrary survey datum). RM2 is the top nut on a fire hydrant on

the upstream side of TH 5 and 105 feet left of the left abutment (elev. 502.54 arbitrary survey datum).

\section{Cross-Sections Used in WSPRO Analysis}

\begin{tabular}{|c|c|c|c|}
\hline${ }^{1}$ Cross-section & $\begin{array}{c}\text { Section } \\
\text { Reference } \\
\text { Distance } \\
\text { (SRD) in feet }\end{array}$ & $\begin{array}{c}{ }^{2} \text { Cross-section } \\
\text { development }\end{array}$ & Comments \\
\hline EXITX & 0 & 1 & Exit section \\
\hline FULLV & 13 & 2 & $\begin{array}{l}\text { Downstream Full-valley } \\
\text { section (Templated from } \\
\text { EXITX) }\end{array}$ \\
\hline BRIDG & 13 & 1 & Bridge section \\
\hline RDWAY & 20 & 1 & Road Grade section \\
\hline APPRO & 64 & 1 & Approach section \\
\hline
\end{tabular}

${ }^{1}$ For location of cross-sections see plan-view sketch included with Level I field form, Appendix E. For more detail on how cross-sections were developed see WSPRO input file. 


\section{Data and Assumptions Used in WSPRO Model}

Hydraulic analyses of the reach were done by use of the Federal Highway Administration's WSPRO step-backwater computer program (Shearman and others, 1986, and Shearman, 1990). The analyses reported herein reflect conditions existing at the site at the time of the study. Furthermore, in the development of the model it was necessary to assume no accumulation of debris or ice at the site. Also, flow was assumed to align with the abutments in the opening. Results of the hydraulic model are presented in the Bridge Hydraulic Summary, appendix B, and figure 7 .

Channel roughness factors (Manning's "n”) used in the hydraulic model were estimated using field inspections at each cross section following the general guidelines described by Arcement and Schneider (1989). Final adjustments to the values were made during the modelling of the reach. Channel " $\mathrm{n}$ " values for the reach ranged from 0.035 to 0.050 , and overbank " $n$ " values ranged from 0.035 to 0.065 .

The starting water surface elevations for the 100- and 500-year discharges were obtained from the water surface profile at cross section "N" provided in the Flood Insurance Study (FIS) for the Town of Castleton (FEMA, 1984). For the incipient roadway-overtopping discharge, the starting water surface elevation was obtained based on a rating of the discharges and water surface elevations computed at cross section N. Each water surface elevation at section "N" from the FIS was assumed to be a satisfactory starting water surface elevation at the exit section (EXITX), which was surveyed for this hydraulic evaluation.

The approach section (APPRO) was surveyed one bridge length upstream of the upstream face as recommended by Shearman and others (1986). This location provides a consistent method for determining scour variables. 


\section{Bridge Hydraulics Summary}

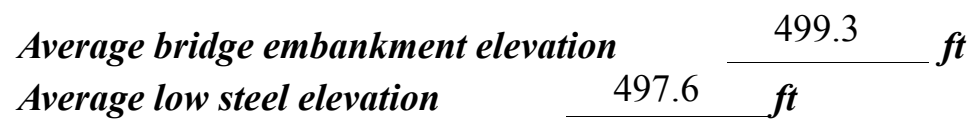

\begin{tabular}{|c|c|c|c|c|}
\hline 100-year discharge & 4,200 & $f t^{3} / s$ & & \\
\hline Water-surface eleva & n bridg & opening & 497.8 & $f t$ \\
\hline Road overtopping? & Yes & Discharge over $r$ & road & 958 \\
\hline Area of flow in brid & ening & $f t^{2}$ & & \\
\hline Average velocity in & openir & 10.0 & $f t / s$ & \\
\hline Maximum WSPRO & elocit & bridge & 12.2 & $f_{t} / \mathrm{s}$ \\
\hline
\end{tabular}

Water-surface elevation at Approach section with bridge Water-surface elevation at Approach section without bridge 500.9 Amount of backwater caused by bridge 1.4 it 499.5

500-year discharge $\quad 5,800 \quad \mathrm{ft}^{3} / \mathrm{s}$

Water-surface elevation in bridge opening $497.8 \boldsymbol{f t}$

$\begin{array}{lllll}\text { Road overtopping? ___ Yes Discharge over road __ 2,474 } & \mathrm{ft}^{3} / \mathrm{s}\end{array}$

Area of flow in bridge opening $\quad 325 \quad \mathrm{ft}^{2}$

Average velocity in bridge opening $10.2 \mathrm{ft} / \mathrm{s}$

Maximum WSPRO tube velocity at bridge 12.5 , s

Water-surface elevation at Approach section with bridge 502.0

Water-surface elevation at Approach section without bridge $\quad 500.9$

Amount of backwater caused by bridge $\quad 1.1, t$

Incipient overtopping discharge $\quad 2,380 \quad \mathrm{ft}^{3} / \mathrm{s}$

Water-surface elevation in bridge opening 497.1 it

Area of flow in bridge opening $\quad 307 \quad \mathrm{ft}^{2}$

Average velocity in bridge opening $\quad 7.8 \quad \mathrm{ft} / \mathrm{s}$

Maximum WSPRO tube velocity at bridge $\quad 10.3 \mathrm{ft} / \mathrm{s}$

Water-surface elevation at Approach section with bridge

Water-surface elevation at Approach section without bridge

497.9

Amount of backwater caused by bridge $\quad$\begin{tabular}{ll}
$0.0 \quad$ it \\
\hline
\end{tabular} 


\section{Scour Analysis Summary}

\section{Special Conditions or Assumptions Made in Scour Analysis}

Scour depths were computed using the general guidelines described in Hydraulic Engineering Circular 18 (Richardson and Davis, 1995). Scour depths were calculated assuming an infinite depth of erosive material and a homogeneous particle-size distribution. The results of the scour analyses for the 100- and 500-year discharges are presented in tables 1 and 2 and the scour depths are shown graphically in figure 8 .

Contraction scour for the incipient roadway-overtopping discharge was computed by use of the Laursen clear-water contraction scour equation (Richardson and Davis, 1995, p. 32, equation 20). At this site, the 100-year and 500-year discharges resulted in submerged orifice flow. Contraction scour at bridges with orifice flow is best estimated by use of the Chang pressure-flow scour equation (oral communication, J. Sterling Jones, October 4, 1996). Thus, contraction scour for these discharges was computed by use of the Chang equation (Richardson and Davis, 1995, p. 145-146).

For comparison, contraction scour for the discharges resulting in orifice flow also was computed by use of the Laursen clear-water contraction scour equation and the Umbrell pressure-flow equation (Richardson and Davis, 1995, p. 144). Results from these computations are presented in appendix F.

Abutment scour was computed by use of the Froehlich equation (Richardson and Davis, 1995, p. 48, equation 28). Variables for the Froehlich equation include the Froude number of the flow approaching the embankments, the length of the embankment blocking flow, and the depth of flow approaching the embankment less any roadway overtopping. 


\section{Scour Results}

Contraction scour:

Main channel

Live-bed scour

Clear-water scour

Depth to armoring

Left overbank

Right overbank

Local scour:

Abutment scour

Left abutment

Right abutment

Pier scour

Pier 1

Pier 2

Pier 3 100-year
discharge 500-year discharge

(Scour depths in feet)

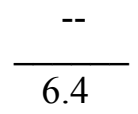

N/A ${ }^{-}$
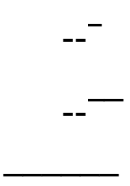

16.6

20.0

14.9

19.2

$20.1-$

$16.1-$
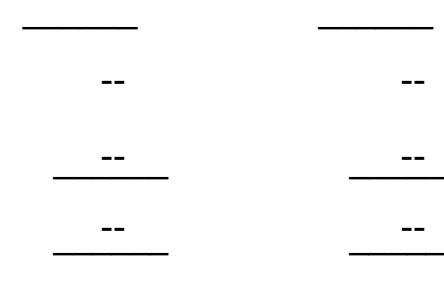

Incipient overtopping discharge 


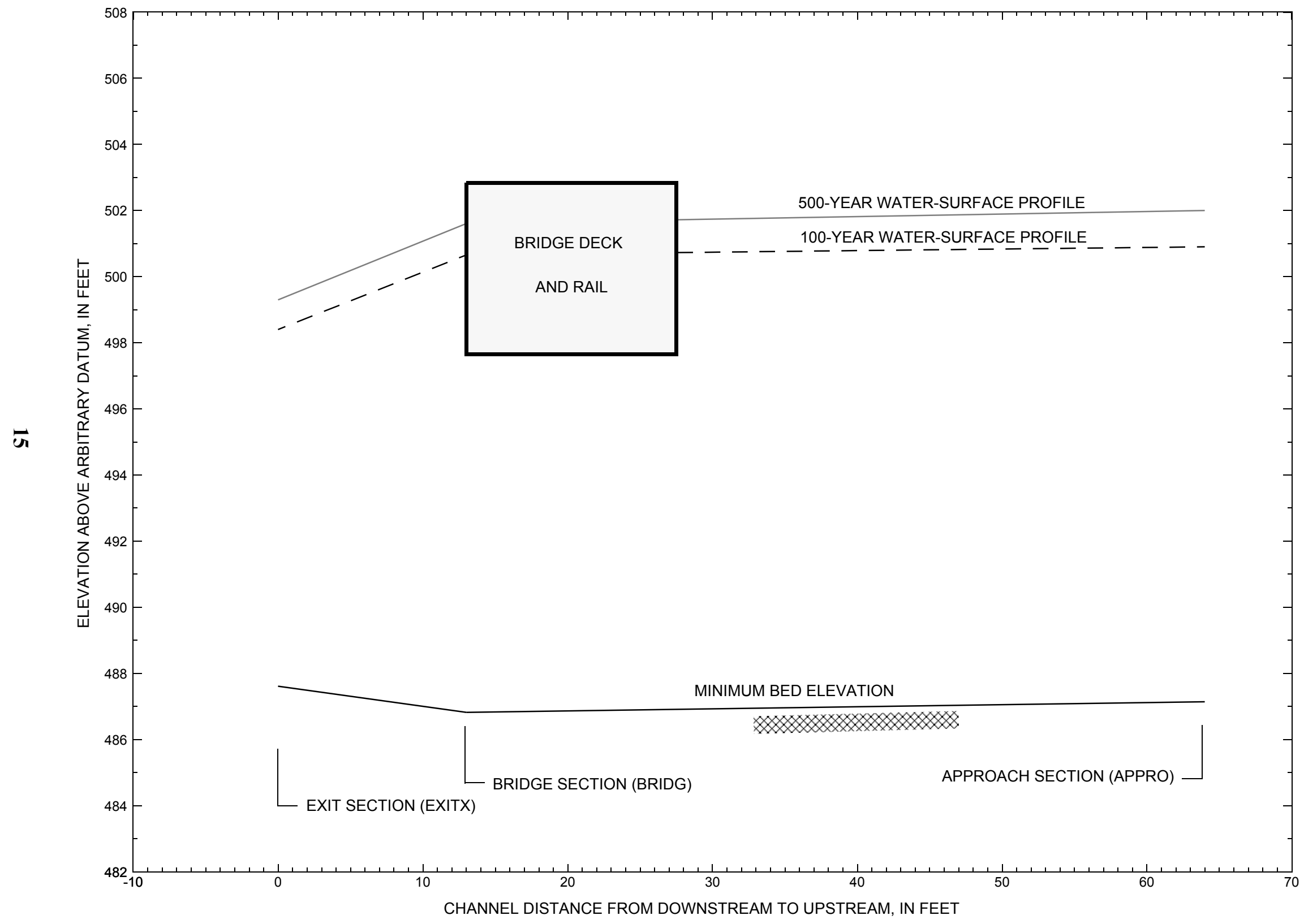

Figure 7. Water-surface profiles for the 100- and 500-year discharges at structure CASTTH00050033 on Town Highway 5, crossing the Castleton River, Castleton, Vermont. 


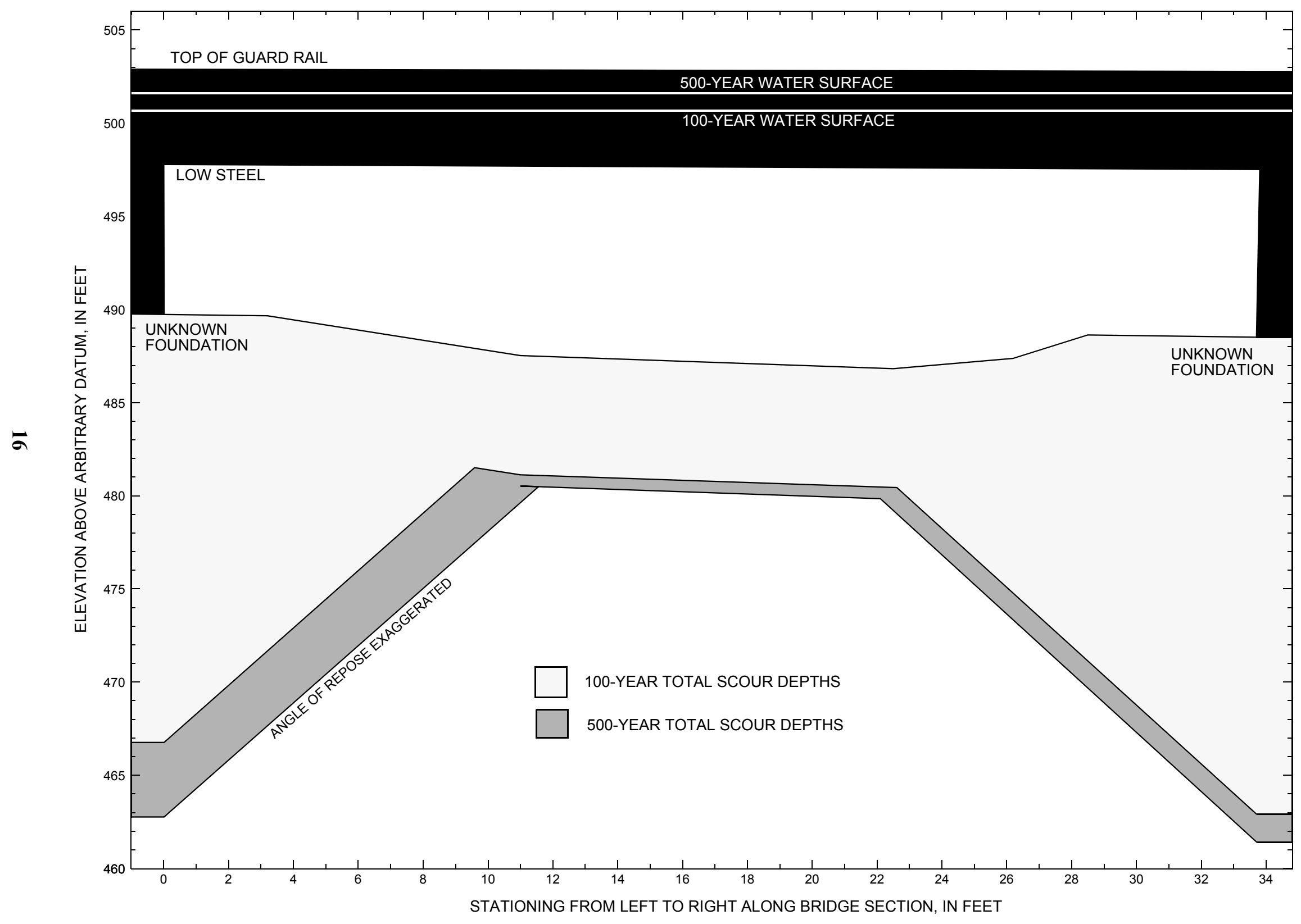

Figure 8. Scour elevations for the 100- and 500-year discharges at structure CASTTH00050033 on Town Highway 5, crossing the Castleton River, Castleton, Vermont. 
Table 1. Remaining footing/pile depth at abutments for the 100-year discharge at structure CASTTH00050033 on Town Highway 5 , crossing the Castleton River, Castleton, Vermont.

[VTAOT, Vermont Agency of Transportation; --, no data]

\begin{tabular}{|c|c|c|c|c|c|c|c|c|c|c|c|}
\hline Description & Station $^{1}$ & $\begin{array}{l}\text { VTAOT } \\
\text { minimum } \\
\text { low-chord } \\
\text { elevation } \\
\text { (feet) }\end{array}$ & $\begin{array}{l}\text { Surveyed } \\
\text { minimum } \\
\text { low-chord } \\
\text { elevation }{ }^{2} \\
\text { (feet) }\end{array}$ & $\begin{array}{c}\text { Bottom of } \\
\text { footing/pile } \\
\text { elevation }{ }^{2} \\
\text { (feet) }\end{array}$ & $\begin{array}{c}\text { Channel } \\
\text { elevation at } \\
\text { abutment/ } \\
\text { pier }^{2} \\
\text { (feet) }\end{array}$ & $\begin{array}{l}\text { Contraction } \\
\text { scour depth } \\
\text { (feet) }\end{array}$ & $\begin{array}{l}\text { Abutment } \\
\text { scour } \\
\text { depth } \\
\text { (feet) }\end{array}$ & $\begin{array}{l}\text { Pier } \\
\text { scour } \\
\text { depth } \\
\text { (feet) }\end{array}$ & $\begin{array}{l}\text { Depth of } \\
\text { total scour } \\
\text { (feet) }\end{array}$ & $\begin{array}{c}\text { Elevation of } \\
\text { scour }^{2} \\
\text { (feet) }\end{array}$ & $\begin{array}{c}\text { Remaining } \\
\text { footing/pile } \\
\text { depth } \\
\text { (feet) }\end{array}$ \\
\hline \multicolumn{12}{|c|}{100 -year discharge is 4,200 cubic-feet per second } \\
\hline Left abutment & 0.0 & -- & 497.8 & -- & 489.8 & 6.4 & 16.6 & -- & 23.0 & 466.8 & -- \\
\hline Right abutment & 33.8 & -- & 497.5 & -- & 488.5 & 6.4 & 19.2 & -- & 25.6 & 462.9 & -- \\
\hline
\end{tabular}

1.Measured along the face of the most constricting side of the bridge.

2.Arbitrary datum for this study.

Table 2. Remaining footing/pile depth at abutments for the 500-year discharge at structure CASTTH00050033 on Town Highway 5, crossing the Castleton River, Castleton, Vermont.

[VTAOT, Vermont Agency of Transportation; --, no data]

\begin{tabular}{|c|c|c|c|c|c|c|c|c|c|c|c|}
\hline Description & Station $^{1}$ & $\begin{array}{l}\text { VTAOT } \\
\text { minimum } \\
\text { low-chord } \\
\text { elevation } \\
\text { (feet) }\end{array}$ & $\begin{array}{c}\text { Surveyed } \\
\text { minimum } \\
\text { low-chord } \\
\text { elevation } \\
\text { (feet) }\end{array}$ & $\begin{array}{c}\text { Bottom of } \\
\text { footing/pile } \\
\text { elevation } \\
\text { (feet) }\end{array}$ & $\begin{array}{c}\text { Channel } \\
\text { elevation at } \\
\text { abutment/ } \\
\text { pier }^{2} \\
\text { (feet) }\end{array}$ & $\begin{array}{l}\text { Contraction } \\
\text { scour depth } \\
\text { (feet) }\end{array}$ & $\begin{array}{c}\text { Abutment } \\
\text { scour } \\
\text { depth } \\
\text { (feet) }\end{array}$ & $\begin{array}{l}\text { Pier } \\
\text { scour } \\
\text { depth } \\
\text { (feet) }\end{array}$ & $\begin{array}{l}\text { Depth of } \\
\text { total scour } \\
\text { (feet) }\end{array}$ & $\begin{array}{c}\text { Elevation of } \\
\text { scour }^{2} \\
\text { (feet) }\end{array}$ & $\begin{array}{c}\text { Remaining } \\
\text { footing/pile } \\
\text { depth } \\
\text { (feet) }\end{array}$ \\
\hline \multicolumn{12}{|c|}{500 -year discharge is 5,800 cubic-feet per second } \\
\hline Left abutment & 0.0 & -- & 497.8 & -- & 489.8 & 7.0 & 20.0 & -- & 27.0 & 462.8 & -- \\
\hline Right abutment & 33.8 & -- & 497.5 & -- & 488.5 & 7.0 & 20.1 & -- & 27.1 & 461.4 & -- \\
\hline
\end{tabular}

1.Measured along the face of the most constricting side of the bridge.

2.Arbitrary datum for this study. 


\section{SELECTED REFERENCES}

Arcement, G.J., Jr., and Schneider, V.R., 1989, Guide for selecting Manning's roughness coefficients for natural channels and flood plains:

U.S. Geological Survey Water-Supply Paper 2339, 38 p.

Barnes, H.H., Jr., 1967, Roughness characteristics of natural channels: U.S. Geological Survey Water-Supply Paper 1849,213 p.

Benson, M. A., 1962, Factors Influencing the Occurrence of Floods in a Humid Region of Diverse Terrain: U.S. Geological Survey WaterSupply Paper 1580-B, 64 p.

Brown, S.A. and Clyde, E.S., 1989, Design of riprap revetment: Federal Highway Administration Hydraulic Engineering Circular No. 11, Publication FHWA-IP-89-016, 156 p.

Federal Emergency Management Agency, 1984, Flood Insurance Study, Town of Castleton, Rutland County, Vermont: Washington, D.C., January 1984.

Federal Highway Administration, 1983, Runoff estimates for small watersheds and development of sound design: Federal Highway Administration Report FHWA-RD-77-158.

Federal Highway Administration, 1993, Stream Stability and Scour at Highway Bridges: Participant Workbook: Federal Highway Administration Report FHWA-HI-91-011.

Froehlich, D.C., 1989, Local scour at bridge abutments in Ports, M.A., ed., Hydraulic Engineering--Proceedings of the 1989 National Conference on Hydraulic Engineering: New York, American Society of Civil Engineers, p. 13-18.

Hayes, D.C.,1993, Site selection and collection of bridge-scour data in Delaware, Maryland, and Virginia: U.S. Geological Survey WaterResources Investigation Report 93-4017, 23 p.

Interagency Advisory Committee on Water Data, 1982, Guidelines for determining flood flow frequency: U.S. Geological Survey, Bulletin 17B of the Hydrology Subcommittee, 190 p.

Johnson, C.G. and Tasker, G.D.,1974, Progress report on flood magnitude and frequency of Vermont streams: U.S. Geological Survey OpenFile Report 74-130, 37 p.

Lagasse, P.F., Schall, J.D., Johnson, F., Richardson, E.V., Chang, F., 1995, Stream Stability at Highway Structures: Federal Highway Administration Hydraulic Engineering Circular No. 20, Publication FHWA-IP-90-014, 144 p.

Laursen, E.M., 1960, Scour at bridge crossings: Journal of the Hydraulics Division, American Society of Civil Engineers, v. 86, no. HY2, p. 39-53.

Potter, W. D., 1957a, Peak rates of runoff in the Adirondack, White Mountains, and Maine woods area, Bureau of Public Roads

Potter, W. D., 1957b, Peak rates of runoff in the New England Hill and Lowland area, Bureau of Public Roads

Richardson, E.V. and Davis, S.R., 1995, Evaluating scour at bridges: Federal Highway Administration Hydraulic Engineering Circular No. 18, Publication FHWA-IP-90-017, 204 p.

Richardson, E.V., Simons, D.B., and Julien, P.Y., 1990, Highways in the river environment: Federal Highway Administration Publication FHWA-HI-90-016.

Ritter, D.F., 1984, Process Geomorphology: W.C. Brown Co., Debuque, Iowa, 603 p.

Shearman, J.O., 1990, User's manual for WSPRO--a computer model for water surface profile computations: Federal Highway Administration Publication FHWA-IP-89-027, 187 p.

Shearman, J.O., Kirby, W.H., Schneider, V.R., and Flippo, H.N., 1986, Bridge waterways analysis model; research report: Federal Highway Administration Publication FHWA-RD-86-108, 112 p.

Talbot, A.N., 1887, The determination of water-way for bridges and culverts.

U.S. Geological Survey, 1964, Poultney, Vermont 7.5 Minute Series quadrangle map: U.S. Geological Survey Topographic Maps, Photorevised 1972, Contour Interval, 20 feet, Scale 1:24,000. 


\section{APPENDIX A: \\ WSPRO INPUT FILE}




\section{WSPRO INPUT FILE (continued)}

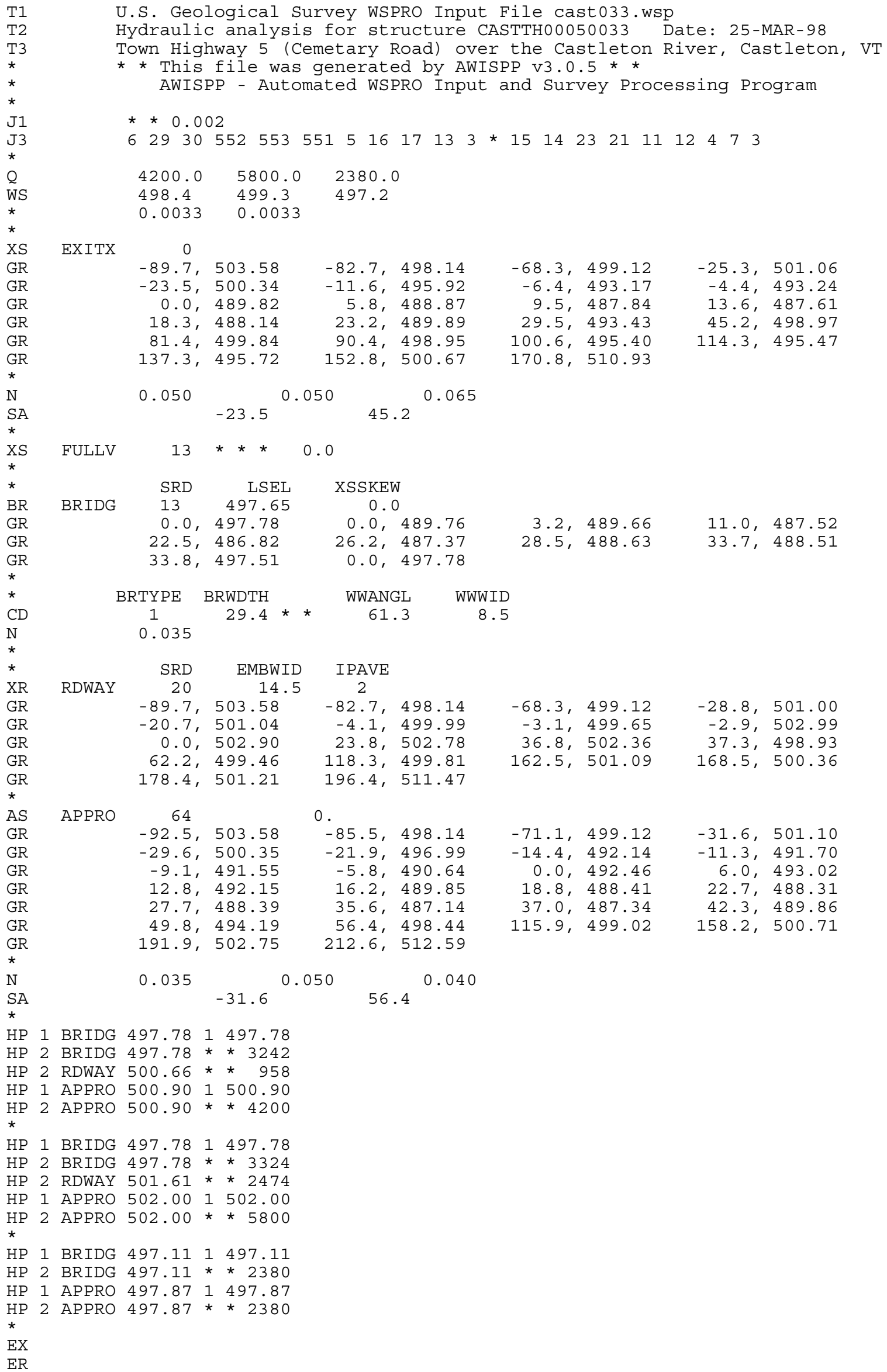




\section{APPENDIX B: \\ WSPRO OUTPUT FILE}




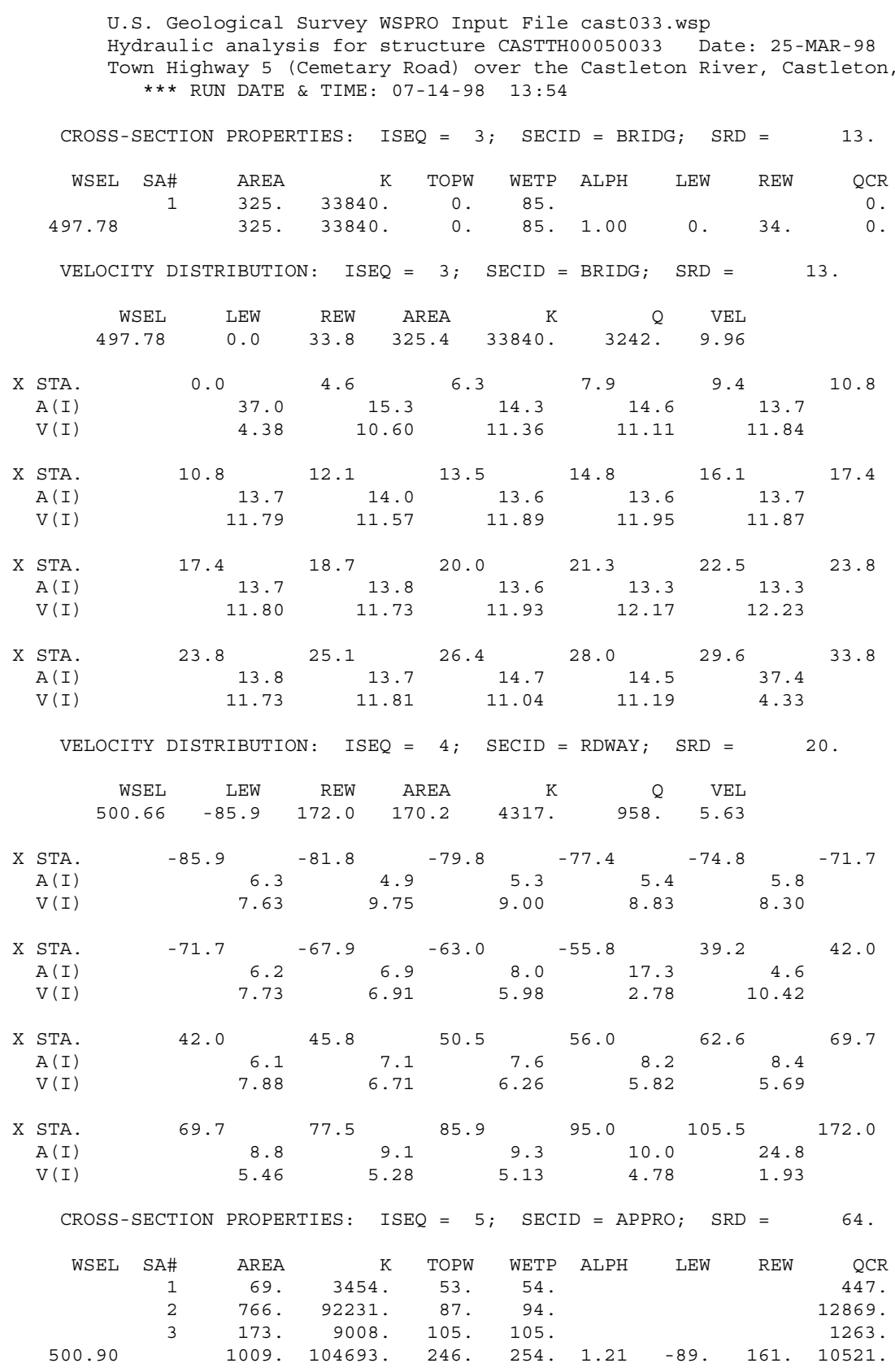

VELOCITY DISTRIBUTION : ISEQ $=5 ; \quad$ SECID $=$ APPRO; $\quad$ SRD $=\quad 64$.

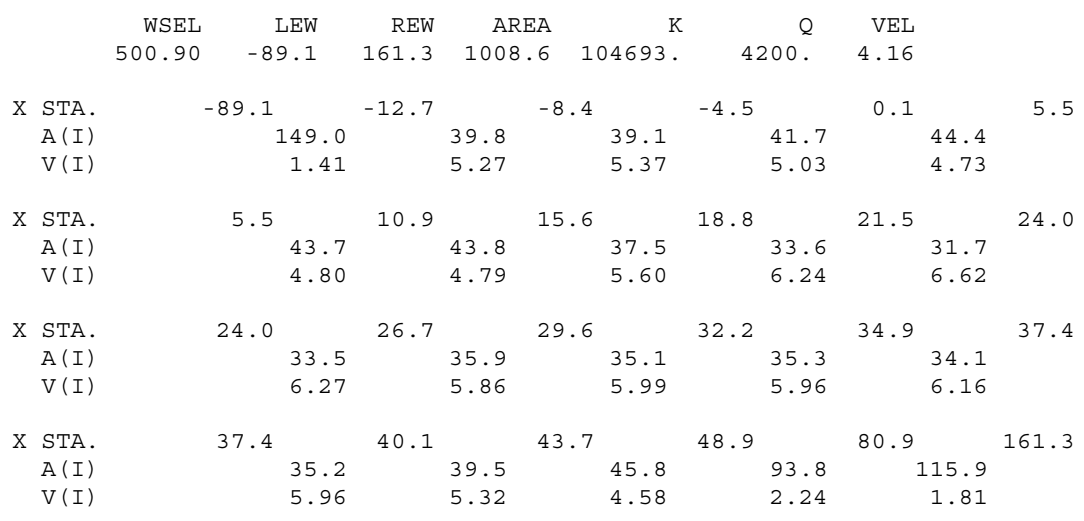


WSPRO FEDERAL HIGHWAY ADMINISTRATION - U. S. GEOLOGICAL SURVEY

V060188 MODEL FOR WATER-SURFACE PROFILE COMPUTATIONS

U.S. Geological Survey WSPRO Input File cast033.wsp

Hydraulic analysis for structure CASTTH00050033 Date: 25-MAR-98

Town Highway 5 (Cemetary Road) over the Castleton River, Castleton, VT *** RUN DATE \& TIME: 07-14-98 13:54

CROSS-SECTION PROPERTIES: ISEQ $=3 ;$ SECID $=$ BRIDG $; \quad$ SRD $=13$.

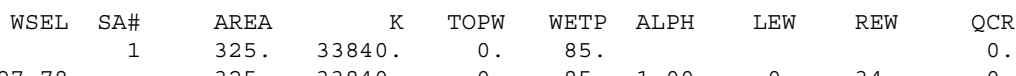

$\begin{array}{llllllll}497.78 & 325 . & 33840 . & 0 . & 85 . & 1.00 & 0 . & 34 .\end{array}$

VELOCITY DISTRIBUTION: ISEQ $=3 ;$ SECID $=$ BRIDG; $\quad$ SRD $=13$.

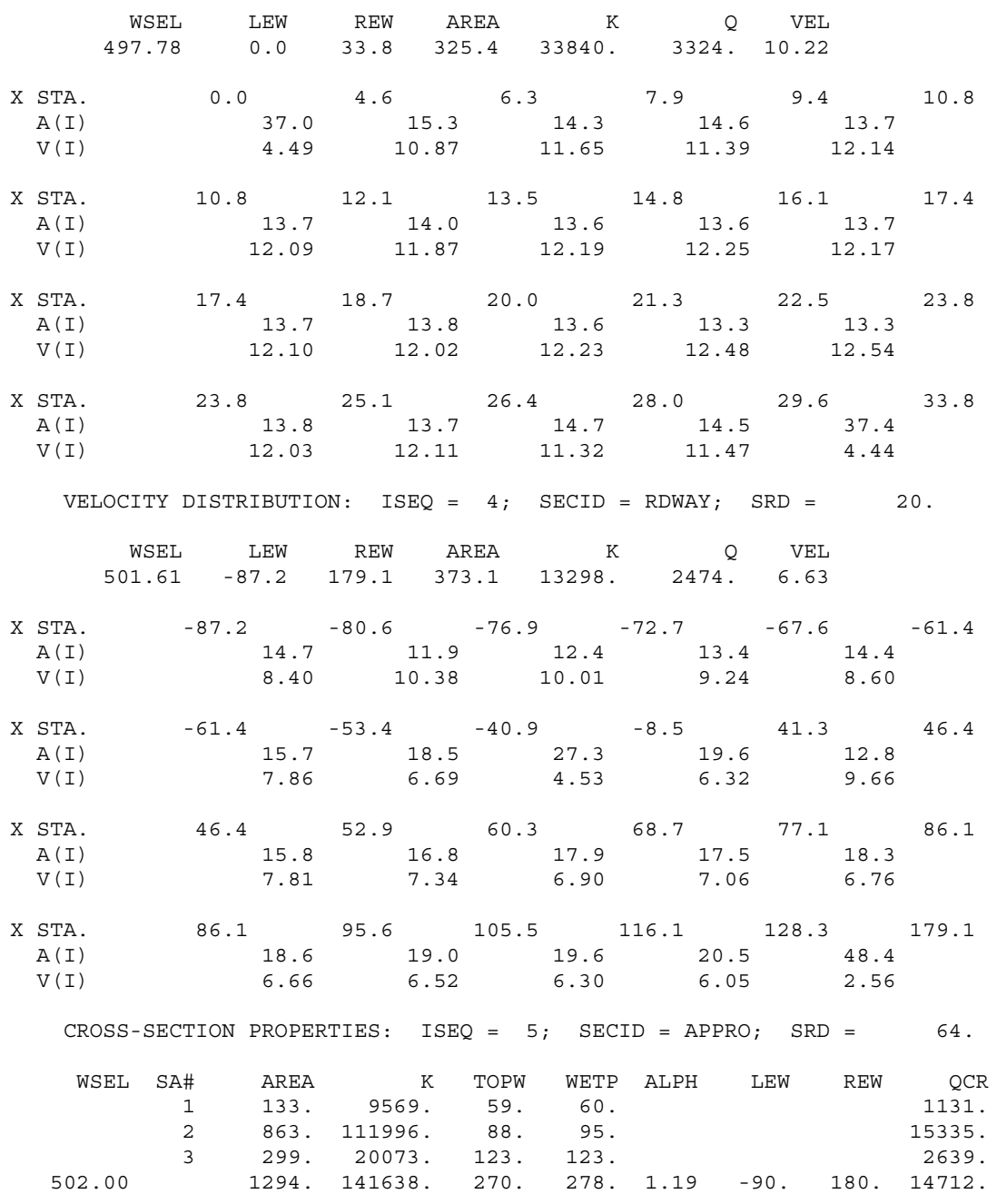

VELOCITY DISTRIBUTION $:$ ISEQ $=5 ; \quad \operatorname{SECID}=\mathrm{APPRO} ; \quad \mathrm{SRD}=64$

\begin{tabular}{|c|c|c|c|c|c|c|c|c|c|c|}
\hline & & WSEI & LEW & REW & $\mathrm{AR}$ & EA & $\mathrm{K}$ & $Q$ & VEL & \\
\hline & & 502.00 & -90.5 & 179.5 & 1294 & .4 & 41638. & 5800 . & 4.48 & \\
\hline$x$ & STA. & & -90.5 & -58.2 & & -12.4 & & -7.7 & -3.2 & 2.2 \\
\hline & $A(I)$ & & 91.2 & & 145.6 & & 49.4 & 49.6 & & \\
\hline & $V(I)$ & & 3.18 & & 1.99 & & 5.87 & 5.85 & & \\
\hline$X$ & STA. & & 2.2 & 8.3 & & 13.9 & & 18.2 & 21.4 & 24.4 \\
\hline & $A(I)$ & & 55.4 & & 54.8 & & 50.8 & 43.4 & & \\
\hline & $V(I)$ & & 5.24 & & 5.29 & & 5.71 & 6.69 & & \\
\hline$x$ & STA. & & 24.4 & 27.6 & & 30.8 & & 33.9 & 36.8 & 40.1 \\
\hline & $A(I)$ & & 44.1 & & 44.8 & & 43.8 & 43.0 & & \\
\hline & $V(I)$ & & 6.57 & & 6.47 & & 6.62 & 6.74 & & \\
\hline & STA. & & 40.1 & 44.1 & & 51.0 & & 76.1 & 103.1 & 179.5 \\
\hline & $A(I)$ & & 48.9 & & 62.5 & & 96.6 & 87.7 & & \\
\hline & $V(I)$ & & 5.92 & & 4.64 & & 3.00 & 3.31 & & \\
\hline
\end{tabular}


WSPRO OUTPUT FILE (continued)

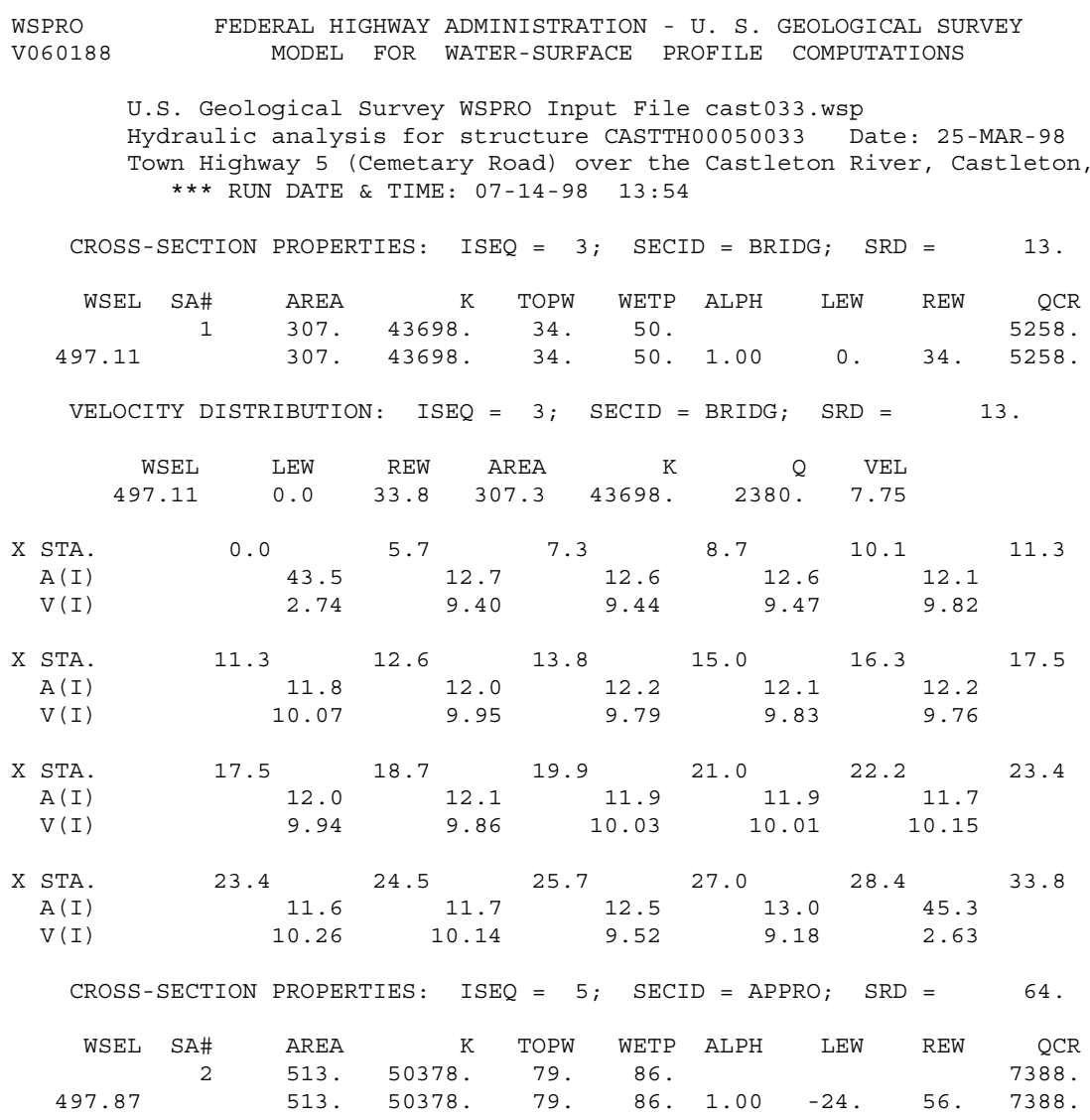

VELOCITY DISTRIBUTION $:$ ISEQ = 5; $\operatorname{SECID~}=\operatorname{APPRO} ; \quad \operatorname{SRD}=\quad 64$.

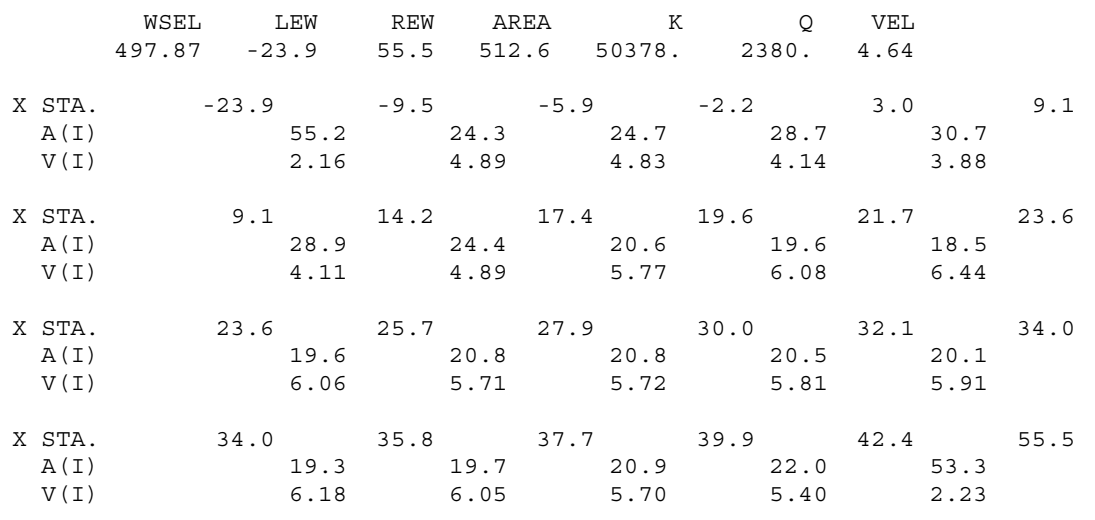


WSPRO OUTPUT FILE (continued)

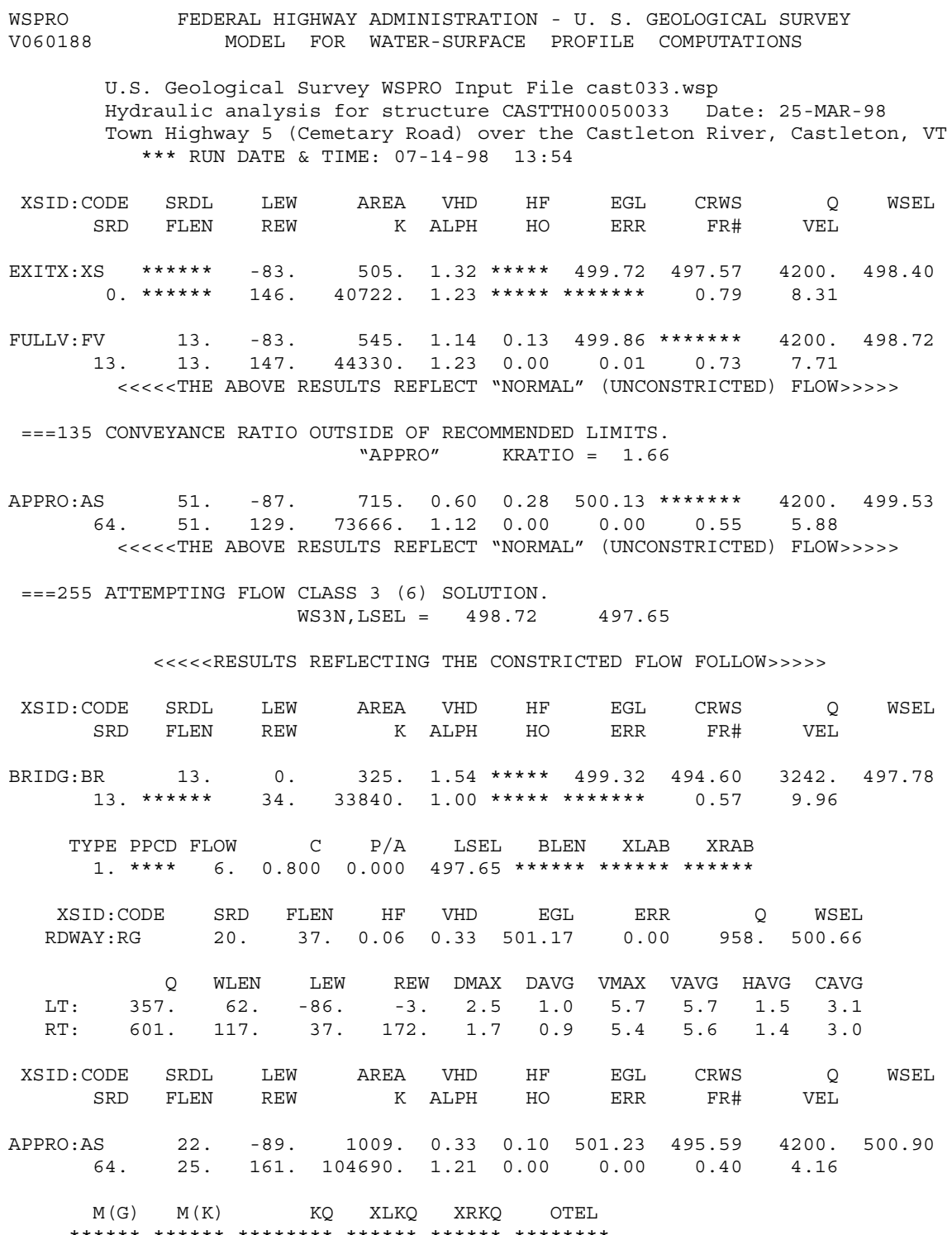


WSPRO OUTPUT FILE (continued)

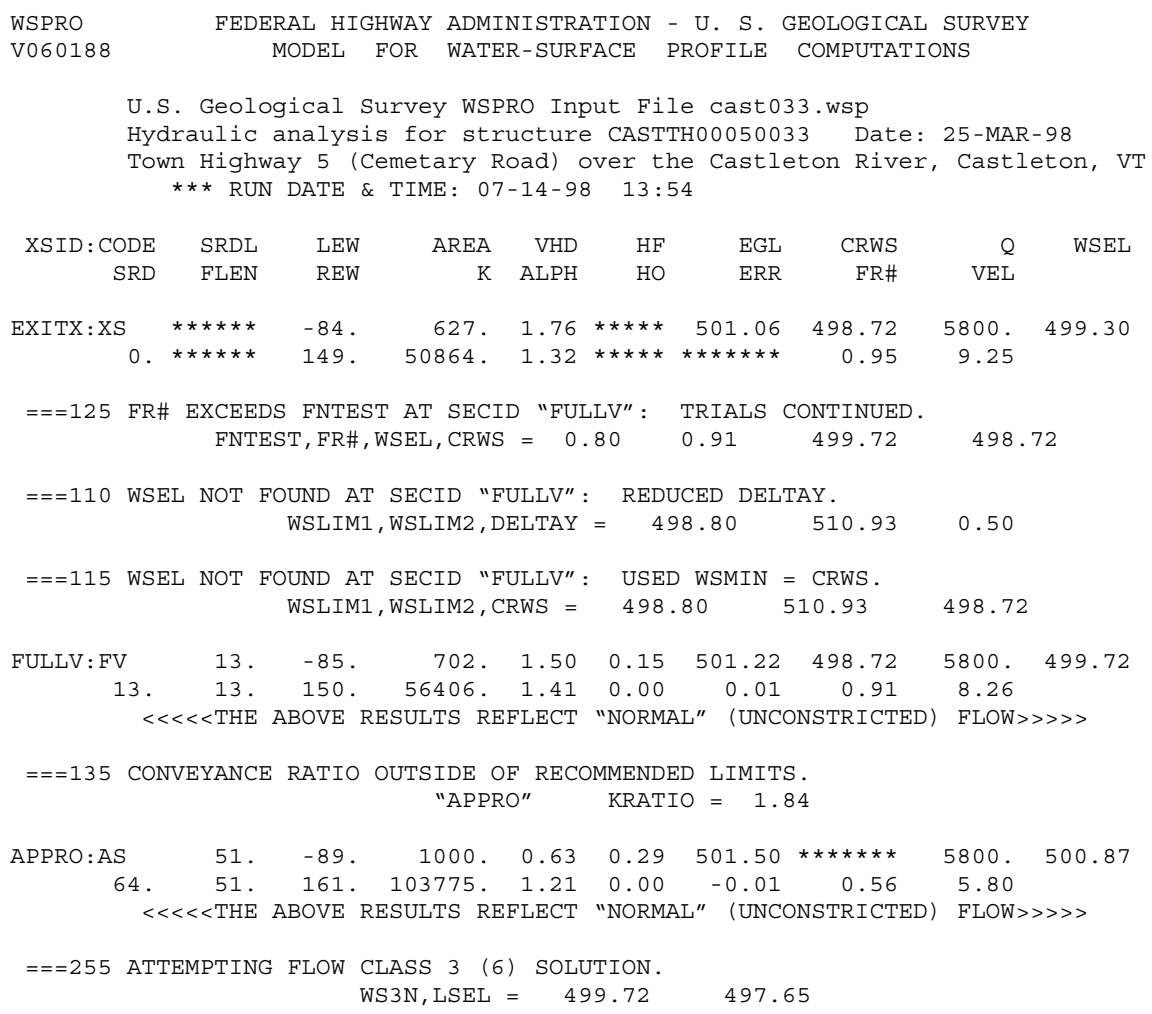

\begin{tabular}{|c|c|c|c|c|c|c|c|c|}
\hline XSID : CODE & SRD & LEW & REW & $\mathrm{Q}$ & K & AREA & VEL & WSEL \\
\hline EXITX:XS & 0. & -84 & 149. & 5800. & 50864. & 627. & 9.25 & 499.30 \\
\hline FULLV : FV & 13. & -85 & 150. & 5800. & 56406 . & 702 . & 8.26 & 499.72 \\
\hline BRIDG : BR & 13. & 0 . & 34. & 3324 . & 33840 . & 325 . & 10.22 & 497.78 \\
\hline RDWAY : RG & 20 .* & $\star \star \star \star * *$ & 912. & 2474 . & $\star * * * * * * * *$ & 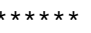 & 2.00 & 501.61 \\
\hline APPRO: AS & 64. & -90 & 179. & 5800. & 141522 . & 1294. & 4.48 & 502.00 \\
\hline XSID : CODE & XLKQ & XRKQ & & & & & & \\
\hline APPRO : AS & & & & & & & & \\
\hline
\end{tabular}

SECOND USER DEFINED TABLE.

\begin{tabular}{|c|c|c|c|c|c|c|c|c|c|}
\hline $\mathrm{XS}$ & CRWS & FR\# & YMIN & MAX & $\mathrm{HF}$ & $\mathrm{HO}$ & VHD & EGL & \\
\hline EIT & 498.72 & 95 & 37.61 & 3 * & & & 1.76 & 1.06 & \\
\hline UL & & & & 0 . & 0.15 & & 50 & 2 & \\
\hline & .71 & & & $.78 *$ & $*$ & $\star \star \star \star * \star$ & 22 & & \\
\hline$\xi$ & $\star \star \star \star$ & $* * * *$ & & & 0 . & $\star \star \star \star \star *$ & 37 & 31 & \\
\hline PPRO : AS & 496.78 & 0.39 & 87.14 & 12.59 & 0.12 & 0.00 & 0.37 & 502.37 & \\
\hline
\end{tabular}


WSPRO OUTPUT FILE (continued)

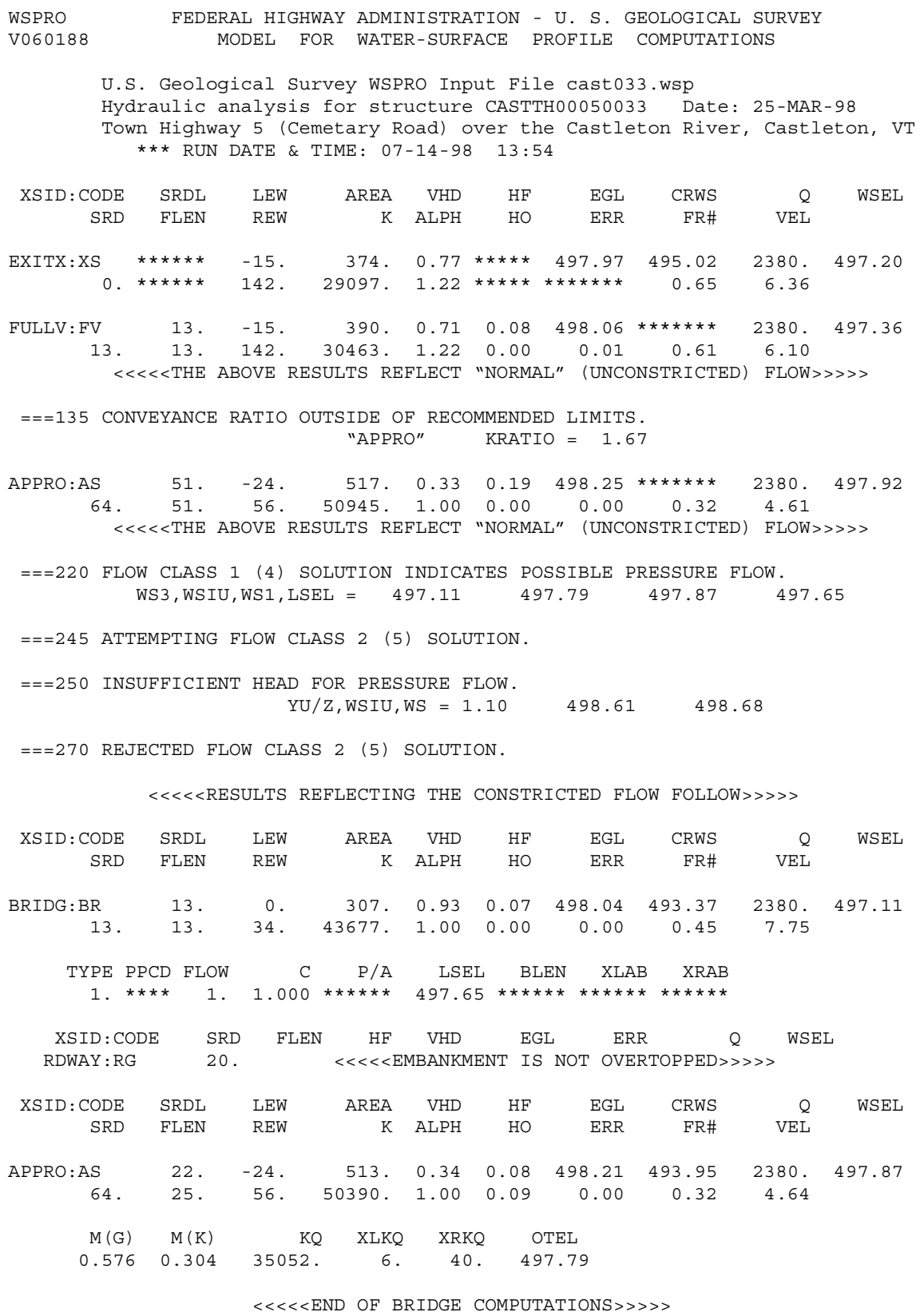

FIRST USER DEFINED TABLE.

\begin{tabular}{|c|c|c|c|c|c|c|c|c|}
\hline XSID : CODE & SRD & LEW & REW & $Q$ & K & AREA & VEL & WSEL \\
\hline EXITX:XS & 0 . & -15 & 142. & 2380. & 29097 . & 374. & 6.36 & 497.20 \\
\hline FULLV : FV & 13. & -15 & 142. & 2380 . & 30463 . & 390. & 6.10 & 497.36 \\
\hline BRIDG : BR & 13. & 0 & 34. & 2380. & 43677 . & 307. & 7.75 & 497.11 \\
\hline RDWAY : RG & \multicolumn{3}{|c|}{$20 . * * * * * * * * * * * * * *$} & \multicolumn{2}{|c|}{$0 . * * * * * * * * *$} & 0 . & \multicolumn{2}{|c|}{$2.00 * \star \star * \star * \star * \star *$} \\
\hline APPRO : AS & 64. & -24 & 56. & 2380. & 50390. & 513. & 4.64 & 497.87 \\
\hline XSID : CODE & XLKQ & XRKQ & & & & & & \\
\hline APPRO:AS & 6 . & 40 & 3505 & & & & & \\
\hline
\end{tabular}

SECOND USER DEFINED TABLE.

\begin{tabular}{|c|c|c|c|c|c|c|c|c|c|}
\hline XSID : CODE & CRWS & FR\# & YMIN & YMAX & $\mathrm{HF}$ & $\mathrm{HO}$ & VHD & EGL & WSEL \\
\hline EXITX:XS & 495.02 & 0.65 & 487.61 & 510.93 * & 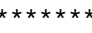 & 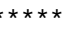 & 0.77 & 497.97 & 497.20 \\
\hline FULLV : FV & 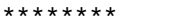 & 0.61 & 487.61 & 510.93 & 0.08 & 0.00 & 0.71 & 498.06 & 497.36 \\
\hline BRIDG : BR & 493.37 & 0.45 & 486.82 & 497.78 & 0.07 & 0.00 & 0.93 & 498.04 & 497.11 \\
\hline RDWAY : RG & $\star * \star * * * * * *$ & $* * * *$ & 498.14 & 511.47 * & $\star * \star * * *$ & 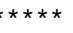 & 0.26 & 498.88 * & 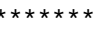 \\
\hline APPRO: AS & 493.95 & 0.32 & 487.14 & 512.59 & 0.08 & 0.09 & 0.34 & 498.21 & 497.87 \\
\hline
\end{tabular}




\section{APPENDIX C:}

\section{BED-MATERIAL PARTICLE-SIZE DISTRIBUTION}




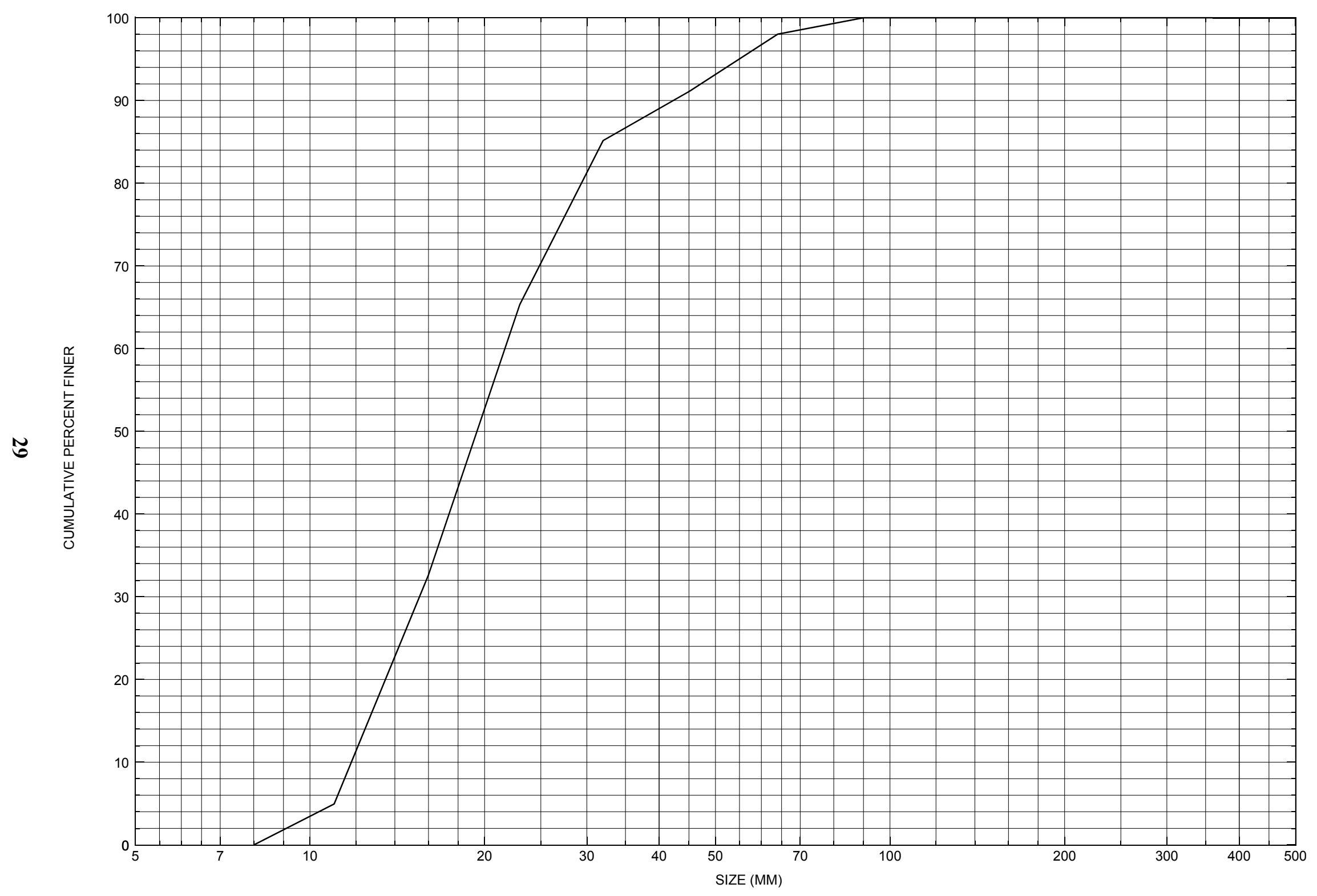

Appendix C. Bed material particle-size distribution for a pebble count in the channel approach of structure CASTTH00050033, in Castleton, Vermont. 


\section{APPENDIX D: \\ HISTORICAL DATA FORM}




\section{Structure Number CASTTH00050033}

\section{General Location Descriptive}

Data collected by (First Initial, Full last name) $\mathbf{E}$. BOEHMLER

Date $(M M / D D / Y Y) \_\mathbf{0 3} / \underline{20} / \underline{95}$

Highway District Number $(I-2 ; n n) \underline{\mathbf{0 3}}$

Town (FIPS place code; I - 4; nnnnn) 11950

Waterway (I - 6) CASTLETON RIVER

Route Number $\underline{\text { TH005 }}$

Topographic Map Poultney

Latitude (I - 16; nnnn.n) $\mathbf{4 3 3 6 7}$
County (FIPS county code; I - 3; nnn)

Mile marker (I - 11; nnn.nnn) $\mathbf{0 0 0 0 0 0}$

Road Name (I - 7): -

Vicinity (I - 9) 0.15 MI TO JCT W TH1

Hydrologic Unit Code: $\mathbf{0 2 0 1 0 0 0 1}$

Longitude (i - 17; nnnnn.n) 73112

\section{Select Federal Inventory Codes}

FHWA Structure Number (I - 8) 10110300331103

Maintenance responsibility $(I-21 ; n n) \quad \mathbf{0 3}$

Year built (I - 27; YYYY) 1908

Average daily traffic, ADT (I - 29; nnnnnn) 000050

Year of ADT (I - 30; YY) $\mathbf{9 2}$

Opening skew to Roadway $(I-34 ; n n) \quad \mathbf{0 0}$

Operational status $(I-41 ; X) \mathbf{R}$

Structure type (I - 43; nnn) $\mathbf{3 0 2}$

Approach span structure type $(I-44 ; n n n) \quad \mathbf{0 0 0}$

Number of spans (I - 45; nnn) $\mathbf{0 0 1}$

Number of approach spans (I - 46; nnnn) $\mathbf{0 0 0 0}$

Comments:

The structural inspection report of 7/13/94 indicates the structure is a single span, steel beam type bridge. The right abutment and its wingwalls are concrete while the left abutment is "laid-up" cut-stone blocks. The right abutment is reported as having areas of spalling and heavy concrete scaling along the bottom of the wall. The left abutment has cracks, breaks, voids, and displacement of the stone reported. Settlement of the left abutment has occurred, reportedly. Its wingwalls are in a condition similar to that of the abutment concrete. The report notes scour along the left abutment, which has created a 3 foot long segment where the stone blocks have fallen out from the wall. Furthermore, scour is reported (Continued, page 33) 


\section{Bridge Hydrologic Data}

Is there hydrologic data available? $\underline{\mathbf{N}}$ if No, type ctrl-n $h \quad$ VTAOT Drainage area $\left(m i^{2}\right)$ : -

Terrain character:

Stream character \& type: -

Streambed material:

Discharge Data (cfs):

$$
\begin{aligned}
& Q_{2.33}- \\
& Q_{50}-
\end{aligned}
$$

Record flood date $(M M / D D / Y Y)$ :

Estimated Discharge (cfs): Ice conditions (Heavy, Moderate, Light) : -

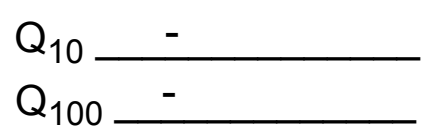

$$
\begin{aligned}
& Q_{25}- \\
& Q_{500}-
\end{aligned}
$$

Water surface elevation $(f t):-$

The stage increases to maximum highwater elevation (Rapidly, Not rapidly):

The stream response is (Flashy, Not flashy):

Describe any significant site conditions upstream or downstream that may influence the stream's stage: -

Watershed storage area (in percent): _ _ \%

The watershed storage area is: - (1-mainly at the headwaters; 2- uniformly distributed; 3-immediatly upstream oi the site)

Water Surface Elevation Estimates for Existing Structure:

\begin{tabular}{|l|l|l|l|l|l|}
\hline Peak discharge frequency & $Q_{2.33}$ & $Q_{10}$ & $Q_{25}$ & $Q_{50}$ & $Q_{100}$ \\
Water surface elevation (ft)) & - & - & - & - & - \\
Velocity (ft/sec) & - & - & - & - & - \\
\hline
\end{tabular}

Long term stream bed changes: -

Is the roadway overtopped below the $\mathrm{Q}_{100}$ ? (Yes, No, Unknown): $\mathbf{U}$ Frequency: Relief Elevation (ft): Discharge over roadway at $Q_{100}\left(f^{3} / \mathrm{sec}\right)$ :

Are there other structures nearby? (Yes, No, Unknown): $\underline{\mathbf{U}}$ Upstream distance (miles): Town: If No or Unknown, type ctrl-n os Highway No. : Structure No. : Year Built:

Clear span (ft): Clear Height $(f t)$ : Full Waterway $\left(f^{2}\right)$ : 
Downstream distance (miles): Town: Year Built:

Highway No. : Structure No. : Structure Type:

Clear span $(f t):$ Clear Height $(f t)$ : Full Waterway $\left(f^{2}\right)$ :

Comments:

through the bridge along the centerline of the stream. The streambed is composed of stones and silt. There is a log across part of the channel upstream from the structure and another tree is hanging over the channel downstream. The majority of the flow is noted to proceed along the upstream right wingwall, and then makes a sharp bend through the structure impacting the left abutment.

\section{USGS Watershed Data}

Watershed Hydrographic Data

Drainage area (DA) $36.87 \mathrm{mi}^{2}$ Lake/pond/swamp area 0.29 $\mathrm{mi}^{2}$

Watershed storage (ST) $\%$

Bridge site elevation 400 $\mathrm{ft}$ Headwater elevation 2726 $\mathrm{ft}$

Main channel length $\mathbf{8 . 4 6}$ $\mathrm{mi}$

$10 \%$ channel length elevation $\mathbf{4 4 0}$ $\mathrm{ft} \quad 85 \%$ channel length elevation $\mathrm{ft}$

Main channel slope $(S)$

(S) 116.69 $\mathrm{ft} / \mathrm{mi}$

Watershed Precipitation Data

Average site precipitation in Average headwater precipitation in

Maximum 2yr-24hr precipitation event $(124,2)$ in

Average seasonal snowfall (Sn) $\mathrm{ft}$ 


\section{Bridge Plan Data}

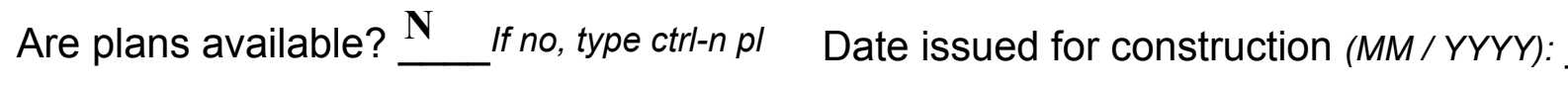

Project Number

Minimum channel bed elevation:

Low superstructure elevation: USLAB DSLAB USRAB DSRAB Benchmark location description:

NO BENCHMARK INFORMATION

Reference Point (MSL, Arbitrary, Other): Datum (NAD27, NAD83, Other):

Foundation Type: 4

If 1 : Footing Thickness

If 2: Pile Type:

If 3: Footing bottom elevation:

Is boring information available? $\mathbf{N}$

Foundation Material Type: $\mathbf{3}$

(1-Spreadfooting; 2-Pile; 3- Gravity; 4-Unknown)

Footing bottom elevation: -

Briefly describe material at foundation bottom elevation or around piles:

NO FOUNDATION MATERIAL INFORMATION 


\section{Cross-sectional Data}

Is cross-sectional data available? Yes If no, type ctrl-n xs

Source (FEMA, VTAOT, Other)? VTAOT

The elevation and station measurements are in feet. This cross section was dated 7/7/92 and Comments: attached to a bridge inspection report. The elevation coordinate was taken from the surveyed points used in this report. They line-up at the low chord points.

\begin{tabular}{|c|c|c|c|c|c|c|c|c|c|c|c|}
\hline Station & $\mathbf{0}$ & 10 & 17.33 & 23.66 & 34.00 & - & - & - & - & - & - \\
\hline Feature & LAB & - & - & - & RAB & - & - & - & - & - & - \\
\hline $\begin{array}{l}\text { Low chord } \\
\text { elevation }\end{array}$ & 497.79 & 497.71 & 497.65 & 497.60 & 497.51 & - & - & - & - & - & - \\
\hline $\begin{array}{l}\text { Bed } \\
\text { elevation }\end{array}$ & 490.04 & 487.29 & 487.15 & 487.10 & 488.43 & - & - & - & - & - & - \\
\hline $\begin{array}{l}\text { Low chord } \\
\text { to bed }\end{array}$ & 7.75 & 10.42 & 10.50 & 10.50 & 9.08 & - & - & - & - & - & - \\
\hline Station & - & - & - & - & - & - & - & - & - & - & - \\
\hline Feature & - & - & - & - & - & - & - & - & - & - & - \\
\hline $\begin{array}{l}\text { Low chord } \\
\text { elevation }\end{array}$ & - & - & - & - & - & - & - & - & - & - & - \\
\hline $\begin{array}{l}\text { Bed } \\
\text { elevation }\end{array}$ & - & - & - & - & - & - & - & - & - & - & - \\
\hline $\begin{array}{l}\text { Low chord } \\
\text { to bed }\end{array}$ & - & - & - & - & - & - & - & - & - & - & - \\
\hline
\end{tabular}

Source (FEMA, VTAOT, Other)?

Comments: -

\begin{tabular}{|l|l|l|l|l|l|l|l|l|l|l|l|l|}
\hline Station & - & - & - & - & - & - & - & - & - & - \\
\hline Feature & - & - & - & - & - & - & - & - & - & - \\
\hline $\begin{array}{l}\text { Low chord } \\
\text { elevation }\end{array}$ & - & - & - & - & - & - & - & - & - & - & - \\
\hline $\begin{array}{l}\text { Bed } \\
\text { elevation }\end{array}$ & - & - & - & - & - & - & - & - & - & - \\
\hline $\begin{array}{l}\text { Low chord } \\
\text { to bed }\end{array}$ & - & - & - & - & - & - & - & - & - & - & - \\
\hline \begin{tabular}{l} 
Station \\
\hline \begin{tabular}{l} 
Feature \\
\hline
\end{tabular}
\end{tabular}$-$ & - & - & - & - & - & - & - & - & - & - & - \\
\hline $\begin{array}{l}\text { Low chord } \\
\text { elevation }\end{array}$ & - & - & - & - & - & - & - & - & - & - \\
\hline $\begin{array}{l}\text { Bed } \\
\text { elevation }\end{array}$ & - & - & - & - & - & - & - & - & - & - \\
\hline $\begin{array}{l}\text { Low chord } \\
\text { to bed }\end{array}$ & - & - & - & - & - & - & - & - & - & - \\
\hline
\end{tabular}




\section{APPENDIX E: \\ LEVEL I DATA FORM}


U. S. Geological Survey

Bridge Field Data Collection and Processing Form

Qa/Qc Check by: MAI Date: $\underline{10 / 25 / 95}$

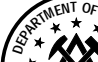

\section{Structure Number CASTTH00050023} Computerized by: MAI Date: 10/25/95

Reviewd by: $\quad$ EMB Date: $\underline{4 / 29 / 98}$

\section{A. General Location Descriptive}

1. Data collected by (First Initial, Full last name) $\underline{\mathbf{T}}$. Severance

Date $(M M / D D / Y Y)$

09

2. Highway District Number $\mathbf{0 3}$

County Rutland (021)

Waterway (I - 6) Castleton River

Route Number TH 5

3. Descriptive comments:

This bridge is located 0.15 mile from the junction of Town Highway 1.
Mile marker $\mathbf{0}$

Town Castleton (11950)

Road Name Cemetery Road

Hydrologic Unit Code: $\mathbf{0 2 0 1 0 0 0 1}$

\section{B. Bridge Deck Observations}
4. Surface cover... LBUS 2
RBUS 2
LBDS 2
RBDS 6
Overall 5

(2b us, ds,lb,rb: 1- Urban; 2- Suburban; 3- Row crops; 4- Pasture; 5- Shrub- and brushland; 6- Forest; 7- Wetland)
5. Ambient water surface... US 1
UB 1
DS 1
(1- pool; 2- riffle)

6. Bridge structure type 1 (1- single span; 2- multiple span; 3- single arch; 4- multiple arch; 5-cylindrical culvert; 6- box culvert; or 7- other)
7. Bridge length $\mathbf{4 1 . 0}$
(feet)
Span length $\underline{\mathbf{3 7 . 0}}$
(feet)
Bridge width 14.5 (feet)

\section{Road approach to bridge:}
8. LB 2
RB 2
( 0 even, 1- lower, 2- higher)
9. LB
RB $\underline{2}$
(1- Paved, 2- Not paved)

10. Embankment slope (run / rise in feet / foot)

US left

US right

\begin{tabular}{|c|c|c|c|}
\hline \multicolumn{2}{|c|}{ Protection } & \multirow{2}{*}{ 13.Erosion } & 14.Severity \\
\hline 11.Type & 12.Cond. & - & $\underline{\mathbf{2}}$ \\
\hline $\mathbf{0}$ & - & $\underline{\mathbf{2}}$ & $\underline{\mathbf{1}}$ \\
\hline $\mathbf{0}$ & - & $\underline{\mathbf{2}}$ & $\underline{\mathbf{1}}$ \\
\hline $\mathbf{0}$ & - & $\mathbf{2}$ & $\mathbf{1}$ \\
\hline $\mathbf{0}$ & - & $\underline{\mathbf{2}}$ & $\mathbf{-}$ \\
\hline
\end{tabular}

Bank protection types: 0- none; 1- < 12 inches;

2- < 36 inches; 3- < 48 inches;

4- < 60 inches; 5- wall / artificial levee

Bank protection conditions: 1- good; 2- slumped;

3- eroded; 4- failed

Erosion: 0 - none; 1- channel erosion; 2-

road wash; 3- both; 4- other

Erosion Severity: 0 - none; 1- slight; 2- moderate; 3- severe

\section{Channel approach to bridge (BF):}

15. Angle of approach: $\mathbf{4 0}$

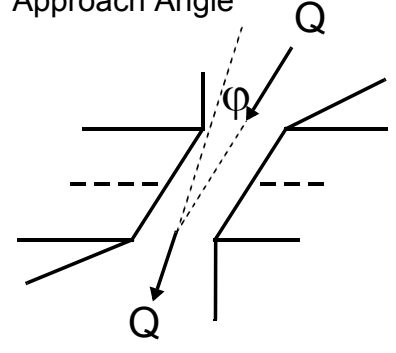

17. Channel impact zone 1 :

Where? RB (LB, RB)

Range? 0 feet $\underline{\text { US }}$

Channel impact zone 2:

Where? LB $(L B, R B)$

Range? $\underline{\mathbf{0}}$ feet $\underline{\mathbf{U S}}$

Impact Severity: 0- none to very slight; 1- Slight; 2- Moderate; 3- Severe
16. Bridge skew: $\mathbf{4 0}$

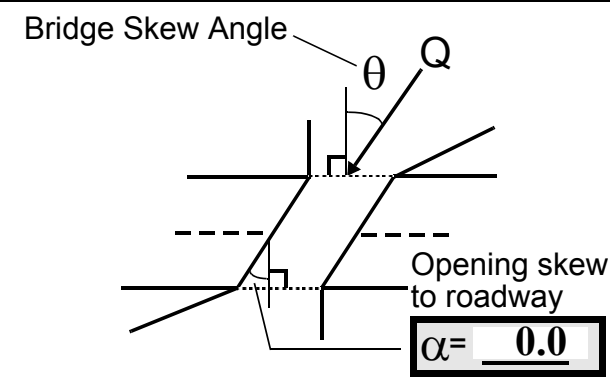

\section{Exist? $\mathbf{Y}(Y$ or $N)$}

Severity 2

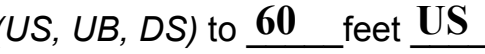

Exist? $\mathbf{Y}(Y$ or $N)$

Severity 1

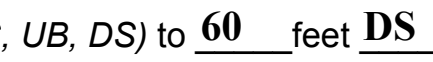


18. Bridge Type: 1a

1a- Vertical abutments with wingwalls

$1 \mathrm{~b}$ - Vertical abutments without wingwalls

2- Vertical abutments and wingwalls, sloping embankment Wingwalls parallel to abut. face

3- Spill through abutments

4- Sloping embankment, vertical wingwalls and abutments

Wingwall angle less than $90^{\circ}$.

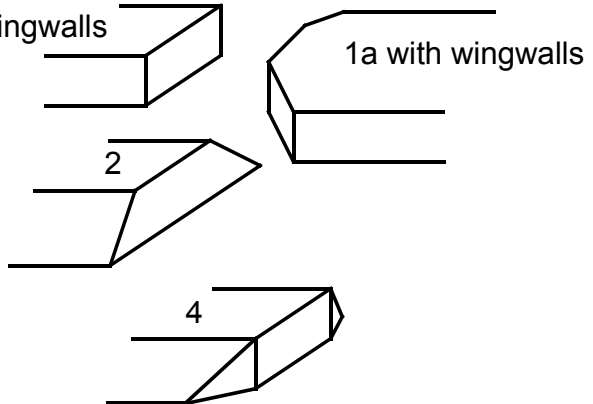

19. Bridge Deck Comments (surface cover variations, measured bridge and span lengths, bridge type variations, approach overflow width, etc.)

4. The surface cover generally is suburban. A railroad bed follows the left bank of the river near this site. In addition to the railroad downstream, the surface cover consists primarily of shrubs and brush. A cemetary and TH 5 occupy the upstream right overbank. On the upstream left overbank, a residential neighborhood was observed with a house and a local roadway following the river. Forest covers the downstream right overbank.

7. The span length and deck width measured were 36.0 feet and 15.0 feet, respectively.

13. Some slumping is evident at the base of the up- and downstream left road embankments.

\section{Upstream Channel Assessment}

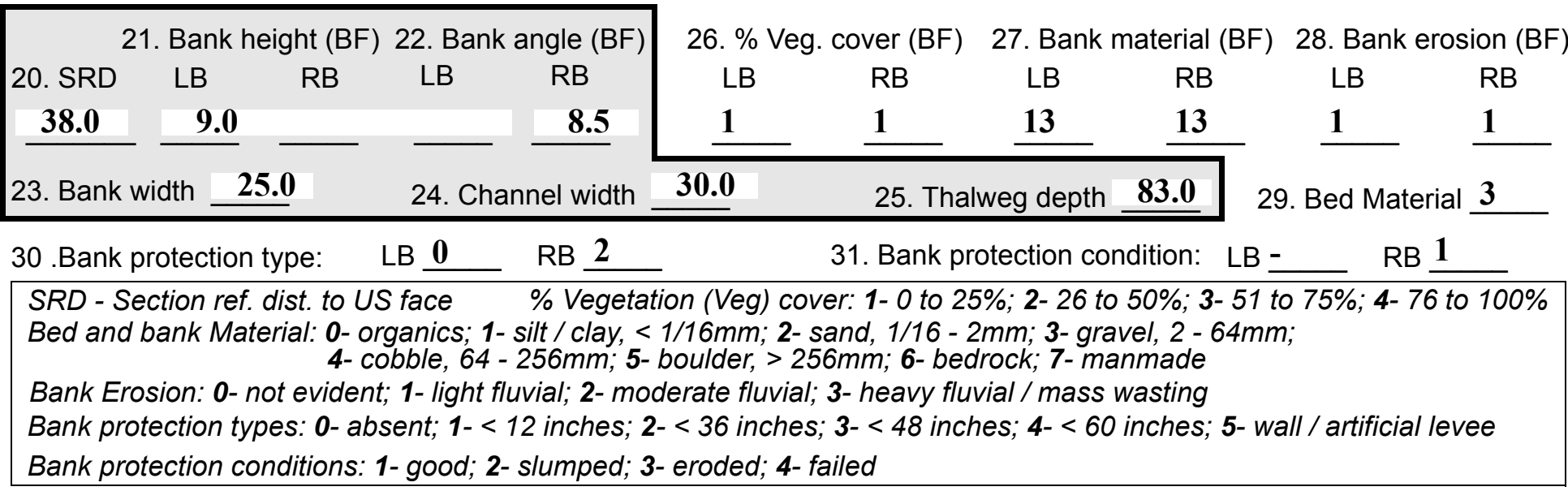

32. Comments (bank material variation, minor inflows, protection extent, etc.):

27. Silty / clay in upper layer with gravel below.

30. Right bank protection extends 65 feet upstream of the upstream right wingwall. 

feet US

(US, UB, DS) positioned $\mathbf{8 0}$ \%LB to $100 \%$ RB

37. Material: $\mathbf{3 2}$

38. Point or side bar comments (Circle Point or Side; Note additional bars, material variation, status, etc.):

This is a gravel point bar with more sand at the US end. A second point bar is located along the right bank from 133 to 167 feet US. The width is 5 feet at the mid-bar distance of 153 feet US and the bar is positioned $80 \%$ left to $100 \%$ right banks. There is grass covering the bar.

39. Is a cut-bank present? $\underline{\mathbf{Y}}$ ( $Y$ or if $N$ type ctrl-n $c b)$

40. Where? $\underline{\mathbf{L B}}$ (LB or RB)

41. Mid-bank distance: $\mathbf{9 5}$

42. Cut bank extent: $\mathbf{5 0}$

\section{(US, UB) 10 .} feet $\underline{\text { US }}$ (US, UB, DS)

43. Bank damage: 3

(1- eroded and/or creep; 2- slip failure; 3- block failure)

44. Cut bank comments (eg. additional cut banks, protection condition, etc.):

Tree roots are exposed with a number of smaller trees leaning into the channel. Much of the finer material has been washed away, leaving gravel along the base of the left bank.

\section{Is channel scour present? $\mathbf{Y}$ (Y or if $N$ type ctrl-n cs) $\quad 46$. Mid-scour distance: 18}
47. Scour dimensions: Length $\mathbf{8 2}$
Width 12
Depth : 2
Position $\underline{\mathbf{5 0}}$
$\%$ LB to $\underline{100} \%$ RB

48. Scour comments (eg. additional scour areas, local scouring process, etc.):

The bed is primarily gravel with little ( 0.2 feet) to no penetration along the scoured section. A mucky layer overlies the gravel along the left bank. There is 1 foot of penetration in areas before hitting gravel; material washes into the channel from the bank and confluence.
49. Are there major confluences? $\mathbf{Y}$
( $Y$ or if $N$ type ctrl-n $m c)$
51. Confluence 1: Distance $\underline{\mathbf{1 4}}$
52. Enters on $\underline{\mathbf{L B}}$
(LB or $R B)$
Confluence 2: Distance -
Enters on - $(L B$ or $R B)$

50. How many? 1

53. Type 1 (1-perennial; 2- ephemeral)

Type (1- perennial; 2- ephemeral)

54. Confluence comments (eg. confluence name):

A ditch enters 10 feet US of the US end of the US left wingwall. The ditch runs along and between the railroad embankment and stream channel.

\section{Under Bridge Channel Assessment}

55. Channel restraint (BF)? LB 2

\begin{tabular}{|ccccc|}
\hline \multicolumn{2}{|c}{ 56. Height (BF) } & \multicolumn{3}{c}{57 Angle (BF) } \\
LB & RB & LB & RB \\
$\mathbf{5 3 . 5}$ & & & $\mathbf{2 . 5}$ & \\
\hline
\end{tabular}

58. Bank width (BF) -

59. Channel width (1- natural bank; 2- abutment; 3- artificial levee)

Bed and bank Material: 0- organics; 1- silt / clay, < 1/16mm; 2- sand, 1/16 - 2mm; 3- gravel, 2 - 64mm; 4- cobble, 64 - 256mm; 5- boulder, > 256mm; 6- bedrock; 7- manmade

Bank Erosion: 0- not evident; 1- light fluvial; 2- moderate fluvial; 3- heavy fluvial / mass wasting

64. Comments (bank material variation, minor inflows, protection extent, etc.):

21

A scour-hole is positioned along the right half of the channel and bed material is composed of fine gravel and course sand. Bed material on the left half of the channel consists of more silt with a penetration of 0.5 feet. The stone protection under the bridge encroaches on the center of the channel. The scour depth under the bridge is 2.5 feet at 8 feet under the bridge and to the right of the center of the channel. 
65. Debris and Ice Is there debris accumulation?

(Yor $N)$ 66. Where? $\underline{Y}$

(1- Upstream; 2- At bridge; 3- Both)

67. Debris Potential 1 (1-Low; 2-Moderate; 3- High)

68. Capture Efficiency 1

(1-Low; 2- Moderate; 3- High)

69. Is there evidence of ice build-up? 1 ( $Y$ or $N)$

Ice Blockage Potential $\mathbf{N}$

(1- Low; 2- Moderate; 3- High)

70. Debris and Ice Comments:

1

There is debris located US along the left bank. A fallen tree mentioned in the structural inspection dated 7/13/94 has been removed.

\begin{tabular}{|l|c|c|c|c|c|c|c|c|}
\hline Abutments & $\begin{array}{c}\text { 71. Attack } \\
\angle \text { (BF) }\end{array}$ & $\begin{array}{c}72 \text {. Slope } \angle \\
\text { (Qmax) }\end{array}$ & $\begin{array}{c}\text { 73. Toe } \\
\text { loc. (BF) }\end{array}$ & $\begin{array}{c}\text { 74. Scour } \\
\text { Condition }\end{array}$ & $\begin{array}{c}75 . \text { Scour } \\
\text { depth }\end{array}$ & $\begin{array}{c}\text { 76. Exposure } \\
\text { depth }\end{array}$ & 77. Material & 78. Length \\
\hline LABUT & & $\mathbf{4 0}$ & $\mathbf{9 0}$ & $\mathbf{2}$ & $\mathbf{0}$ & - & - & $\mathbf{9 0 . 0}$ \\
\hline RABUT & $\mathbf{2}$ & $\mathbf{0}$ & $\mathbf{9 0}$ & & & $\mathbf{2}$ & $\mathbf{2}$ & $\mathbf{3 4 . 0}$ \\
\hline
\end{tabular}

Pushed: $L B$ or RB

Toe Location (Loc.): 0- even, 1- set back, 2- protrudes

Scour cond.: 0- not evident; 1- evident (comment); 2- footing exposed; 3-undermined footing; 4- piling exposed; 5- settled; 6- failed

Materials: 1- Concrete; 2- Stone masonry or drywall; 3- steel or metal; 4- wood

79. Abutment comments (eg. undermined penetration, unusual scour processes, debris, etc.):

0.5

1.2

1

74. The right abutment footing is exposed at the downstream end. Beyond 2 feet in either direction the footing is covered by stone fill. The downstream end of the right wingwall is met by bank protection covered with sand.

80. Wingwalls:

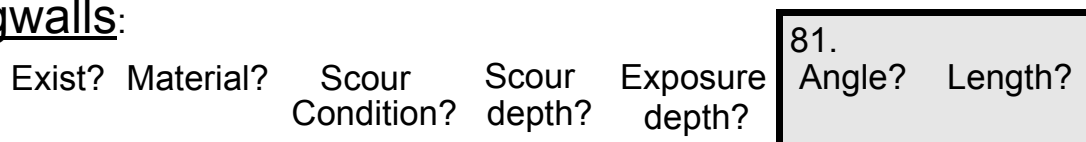

USLWW:

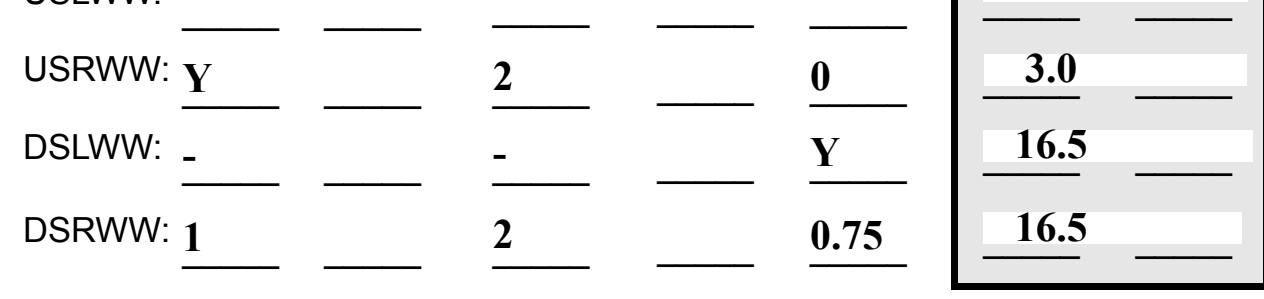

Wingwall materials: 1- Concrete; 2- Stone masonry or drywall; 3- steel or metal; 4- wood

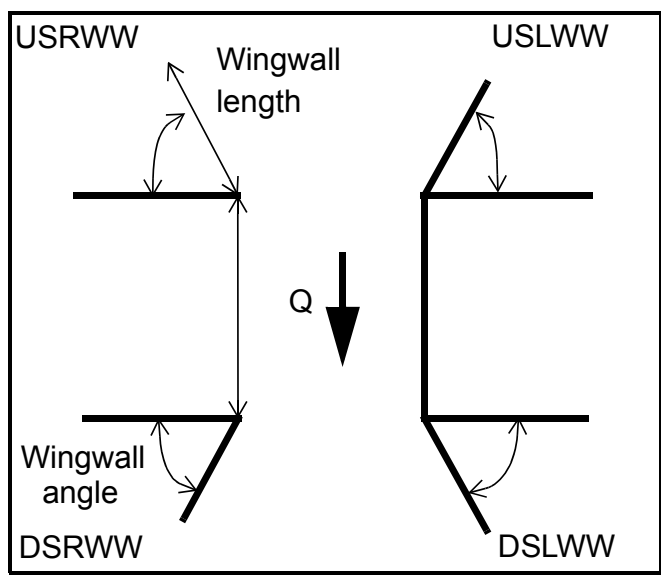

82. Bank / Bridge Protection:

\begin{tabular}{|l|l|l|l|l|l|l|l|c|}
\hline Location & USLWW & USRWW & LABUT & RABUT & LB & RB & DSLWW & DSRWW \\
\hline Type & $\mathbf{1 . 2 5}$ & - & $\mathbf{Y}$ & - & $\mathbf{2}$ & $\mathbf{2}$ & $\mathbf{2}$ & $\mathbf{2}$ \\
\hline Condition & $\mathbf{N}$ & - & $\mathbf{1}$ & - & $\mathbf{1}$ & $\mathbf{2}$ & $\mathbf{1}$ & $\mathbf{3}$ \\
\hline Extent & - & - & $\mathbf{0}$ & $\mathbf{2}$ & $\mathbf{1}$ & $\mathbf{1}$ & $\mathbf{1}$ & - \\
\hline
\end{tabular}

Bank / Bridge protection types: 0- absent; 1- < 12 inches; 2- < 36 inches; 3- < 48 inches; 4- < 60 inches; 
83. Wingwall and protection comments (eg. undermined penetration, unusual scour processes, etc.):

-
-
-
-
-
0
-
-
0
-
-

\section{Piers:}

84. Are there piers? Th (Y or if $N$ type ctrl-n pr)

\begin{tabular}{|l|c|l|l|l|l|l|l|}
\hline \multirow{2}{*}{$\begin{array}{l}85 . \\
\text { Pier no. }\end{array}$} & \multicolumn{3}{|c|}{ width (w) feet } & \multicolumn{3}{c|}{ elevation (e) feet } \\
\cline { 2 - 8 } & w1 & w2 & w3 & e@w1 & e@w2 & e@w3 \\
\hline Pier 1 & & & & $\mathbf{9 0 . 0}$ & $\mathbf{1 4 . 5}$ & $\mathbf{3 5 . 0}$ \\
\hline Pier 2 & & - & & $\mathbf{2 0 . 0}$ & - & $\mathbf{3 0 . 0}$ \\
\hline Pier 3 & $\mathbf{8 . 0}$ & - & - & - & - & - \\
\hline Pier 4 & - & - & - & - & - & - \\
\hline
\end{tabular}

\begin{tabular}{|l|l|l|l|l|}
\hline Level 1 Pier Descr. & \multicolumn{1}{|c|}{1} & \multicolumn{1}{|c|}{2} & \multicolumn{1}{|c|}{3} & \multicolumn{1}{|c|}{4} \\
\hline 86. Location (BF) & e & cov- & wall & detect \\
\hline 87. Type & upst & ered & has & pro- \\
\hline 88. Material & ream & by & par- & tec- \\
\hline 89. Shape & left & slum & tially & tion. \\
\hline 90. Inclined? & wing & ped & falle & DS \\
\hline 91. Attack $\angle$ (BF) & wall & eart & n & right \\
\hline 92. Pushed & pro- & h/ & into & wing \\
\hline 93. Length (feet) & - & - & - & - \\
\hline 94. \# of piles & tec- & grass & the & wall- \\
\hline 95. Cross-members & tion & - & chan & no \\
\hline 96. Scour Condition & is & DS & nel- & pro- \\
\hline 97. Scour depth & most & left & unab & tec- \\
\hline 98. Exposure depth & ly & wing & le to & tion \\
\hline
\end{tabular}

LFP, LTB, LB, MCL, MCM, MCR, RB, RTB, RFP

1- Solid pier, 2- column, 3- bent

1-Wood; 2- concrete; 3- metal; 4- stone

1- Round; 2- Square; 3- Pointed

Y-yes; $N$ - no

$L B$ or $R B$

0- none; 1- laterals; 2- diagonals; 3- both

0- not evident; 1- evident (comment);

2- footing exposed; 3- piling exposed;

4- undermined footing; 5- settled; 6-failed 
99. Pier comments (eg. undermined penetration, protection and protection extent, unusual scour processes, etc.):

detected, but unable to penetrate hard earth (road wash path) some slate (flat) pieces line the surface and are reducing and eliminating road wash effects below the road surface.

$\mathbf{N}$

100.

\section{E. Downstream Channel Assessment}

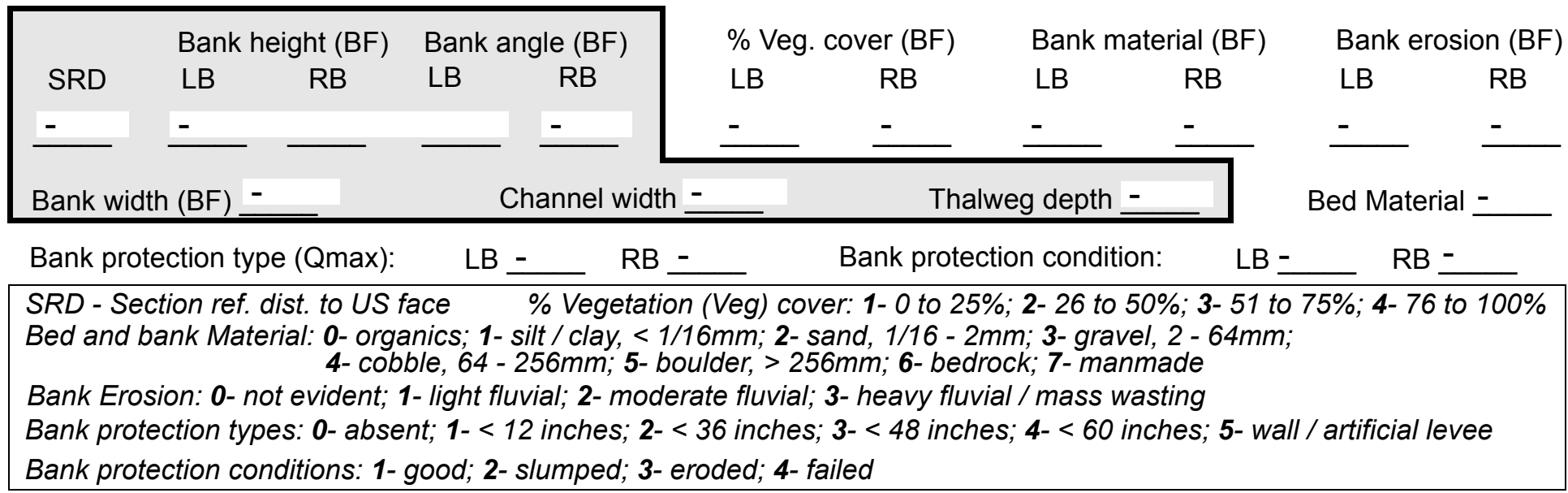

Comments (eg. bank material variation, minor inflows, protection extent, etc.):

$-$

$-$

-

-

-

-

-

-

-

$-$

$-$

\section{Is a drop structure present? _ ( $Y$ or $N$, if $N$ type ctrl-n ds) 102. Distance: _ _ feet}
103. Drop: - feet
104. Structure material: -
(1- steel sheet pile; 2- wood pile; 3- concrete; 4- other)

105. Drop structure comments (eg. downstream scour depth):

-

-

-

- 
106. Point/Side bar present? (Y or $N$. if $N$ type ctrl-n pb)Mid-bar distance:

Mid-bar width: -

Point bar extent: feet -

(US, UB, DS) to feet (US, UB, DS) positioned $\%$ LB to $\% \mathrm{RB}$ Material:

Point or side bar comments (Circle Point or Side; note additional bars, material variation, status, etc.):

S a cut-bank present? $\mathbf{N}$ (Y or if $N$ type ctrl-n cb) Where? $\underline{\mathbf{O}}$ (LB or RB) Mid-bank distance: PIE Cut bank extent: $\underline{\mathbf{R S}}$ feet __ (US, UB, DS) to feet __ (US, UB, DS)

Bank damage: (1- eroded and/or creep; 2- slip failure; 3- block failure)

Cut bank comments (eg. additional cut banks, protection condition, etc.):

Is channel scour present? ( $Y$ or if $N$ type ctrl-n $c s)$ Width 5 Depth: 5

Mid-scour distance: 1 Scour dimensions: Length $\underline{2}$ $\%$ LB to $\underline{\mathbf{0}} \%$ RB

Scour comments (eg. additional scour areas, local scouring process, etc.):

432

3

3

1

Are there major confluences? 1 ( 1 or if $N$ type ctrl-n $m c)$

How many? Ther

Confluence 1: Distance e is Enters on ston (LB or RB)

Type e fill (1-perennial; 2- ephemeral)

Confluence 2: Distance pro-

Enters on tec- (LB or RB)

Type tion (1- perennial; 2- ephemeral)

Confluence comments (eg. confluence name):

along both left and right banks for greater than 100 feet downstream.

Stone fill lines the channel bed from 0 to 70 feet DS.

\section{F. Geomorphic Channel Assessment}

107. Stage of reach evolution

1- Constructed

2- Stable

3- Aggraded

4- Degraded

5- Laterally unstable

6- Vertically and laterally unstable 
108. Evolution comments (Channel evolution not considering bridge effects; See HEC-20, Figure 1 for geomorphic descriptors): 


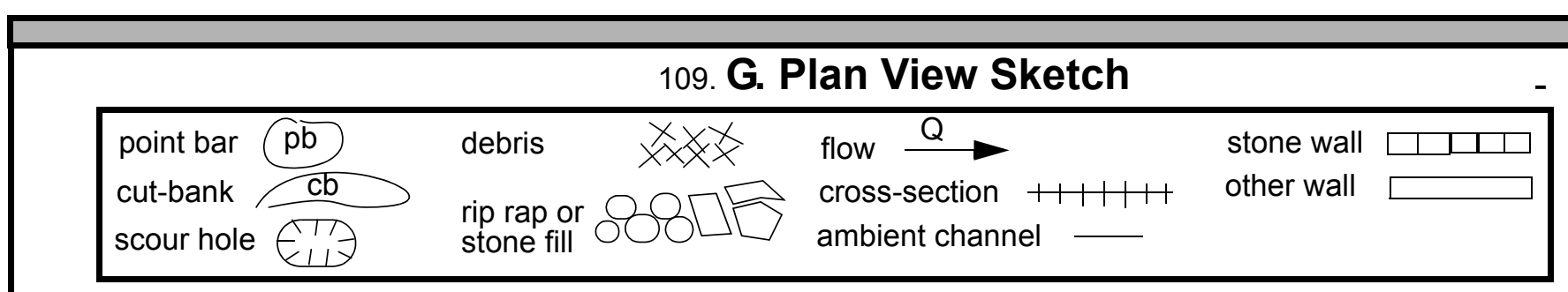


APPENDIX F:

SCOUR COMPUTATIONS 
SCOUR COMPUTATIONS

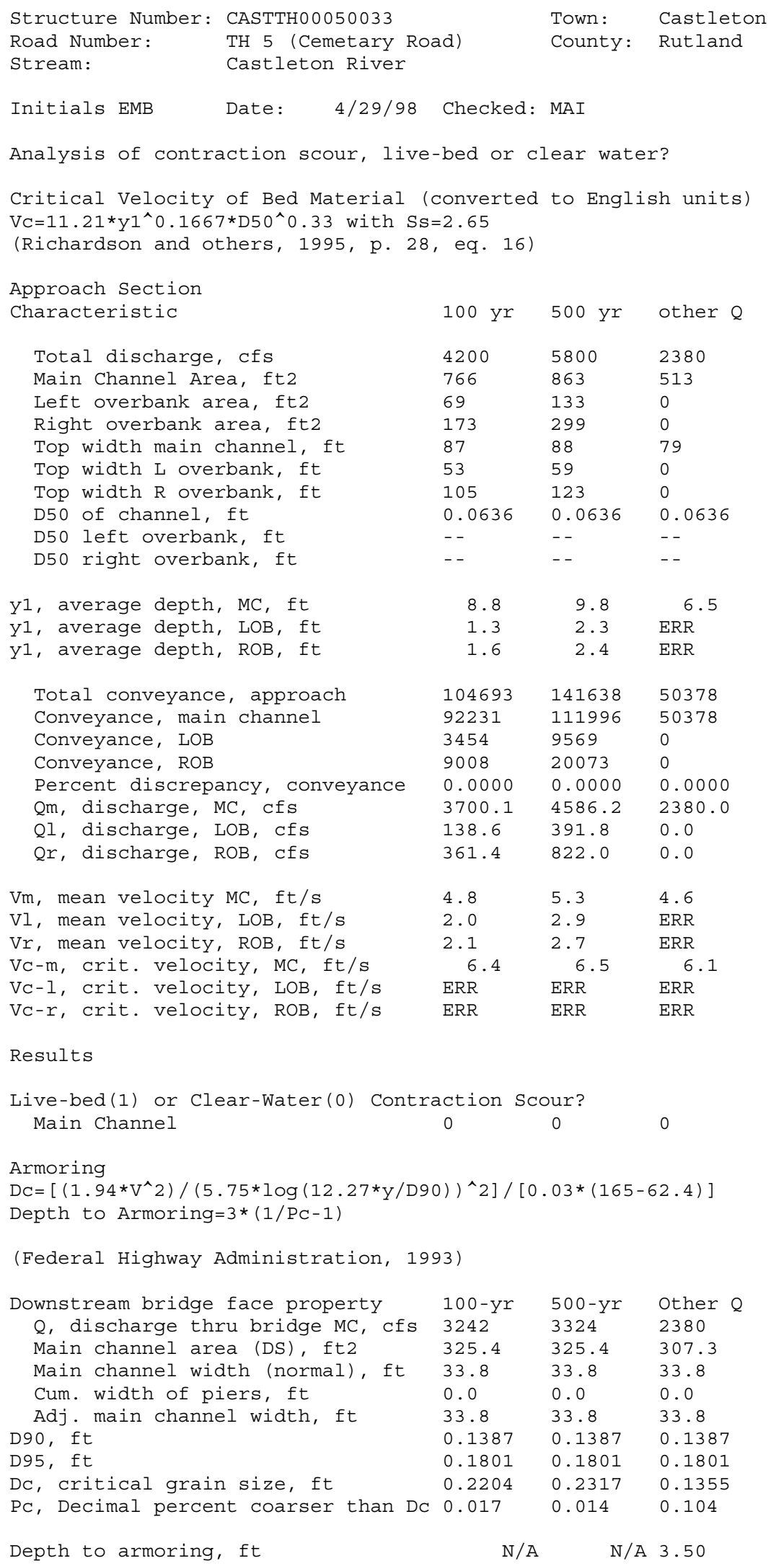


Clear water Contraction Scour in MAIN CHANNEL

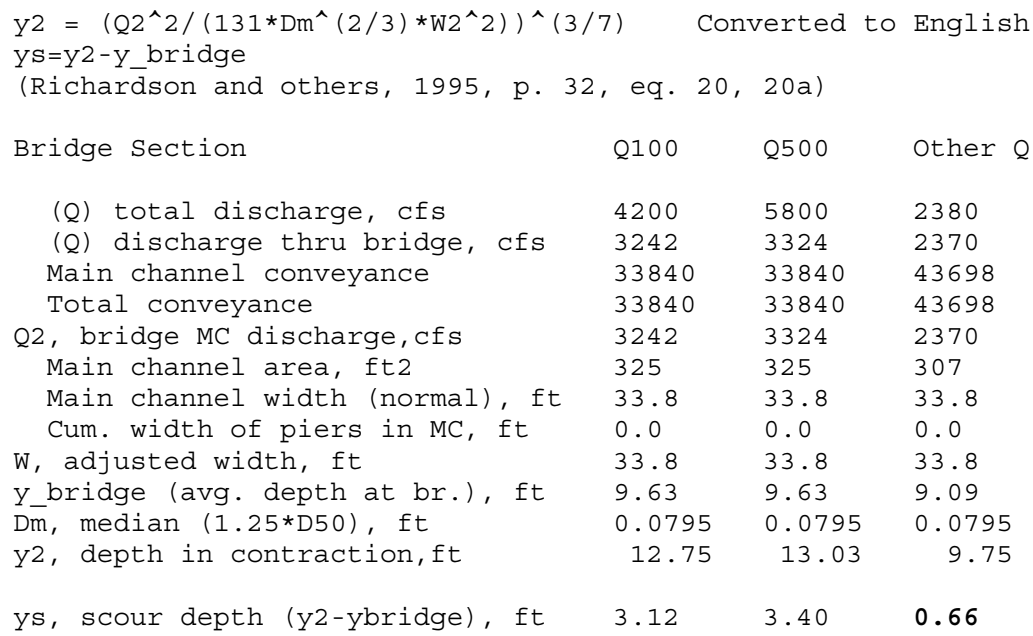

Pressure Flow Scour (contraction scour for orifice flow conditions)

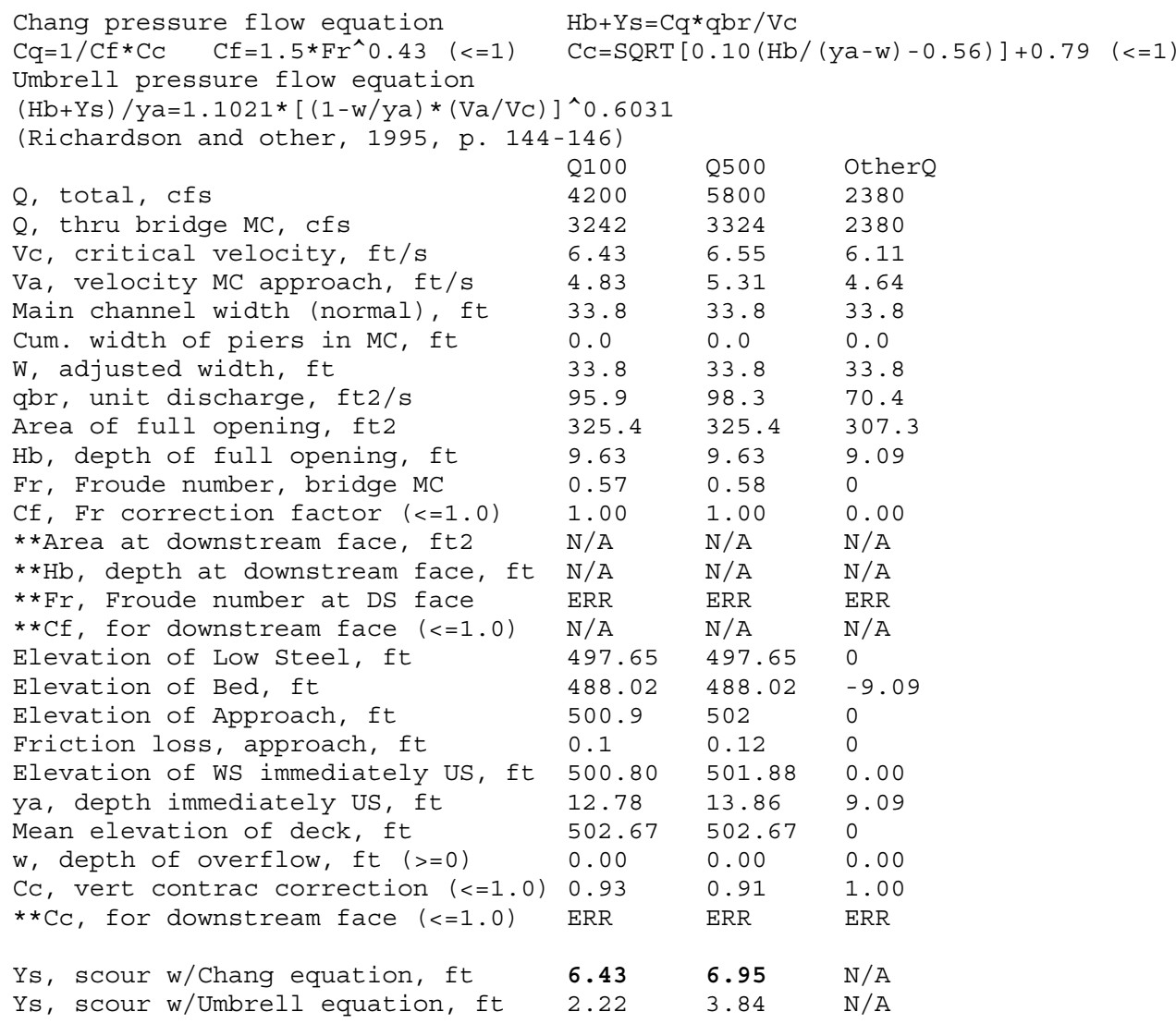

**=for UNsubmerged orifice flow using estimated downstream bridge face properties.

**Ys, scour w/Chang equation, ft $\mathrm{N} / \mathrm{A} \quad \mathrm{N} / \mathrm{A} \quad \mathrm{N} / \mathrm{A}$

**Ys, scour w/Umbrell equation, ft N/A N/A ERR

In UNsubmerged orifice flow, an adjusted scour depth using the Laursen equation results and the estimated downstream bridge face properties can also be computed (ys=y2-ybridgeDs)

$\begin{array}{llll}\text { Y2, from Laursen's equation, ft } 12.75 & 13.03 & 9.75 \\ \text { WSEL at downstream face, ft } & -- & -- & -- \\ \text { Depth at downstream face, ft } & \text { N/A } & \text { N/A } & \text { N/A } \\ \text { depth of scour (Laursen), ft } & \text { N/A } & \text { N/A } & \text { N/A }\end{array}$

Ys, depth of scour (Laursen), ft N/A N/A N/A 


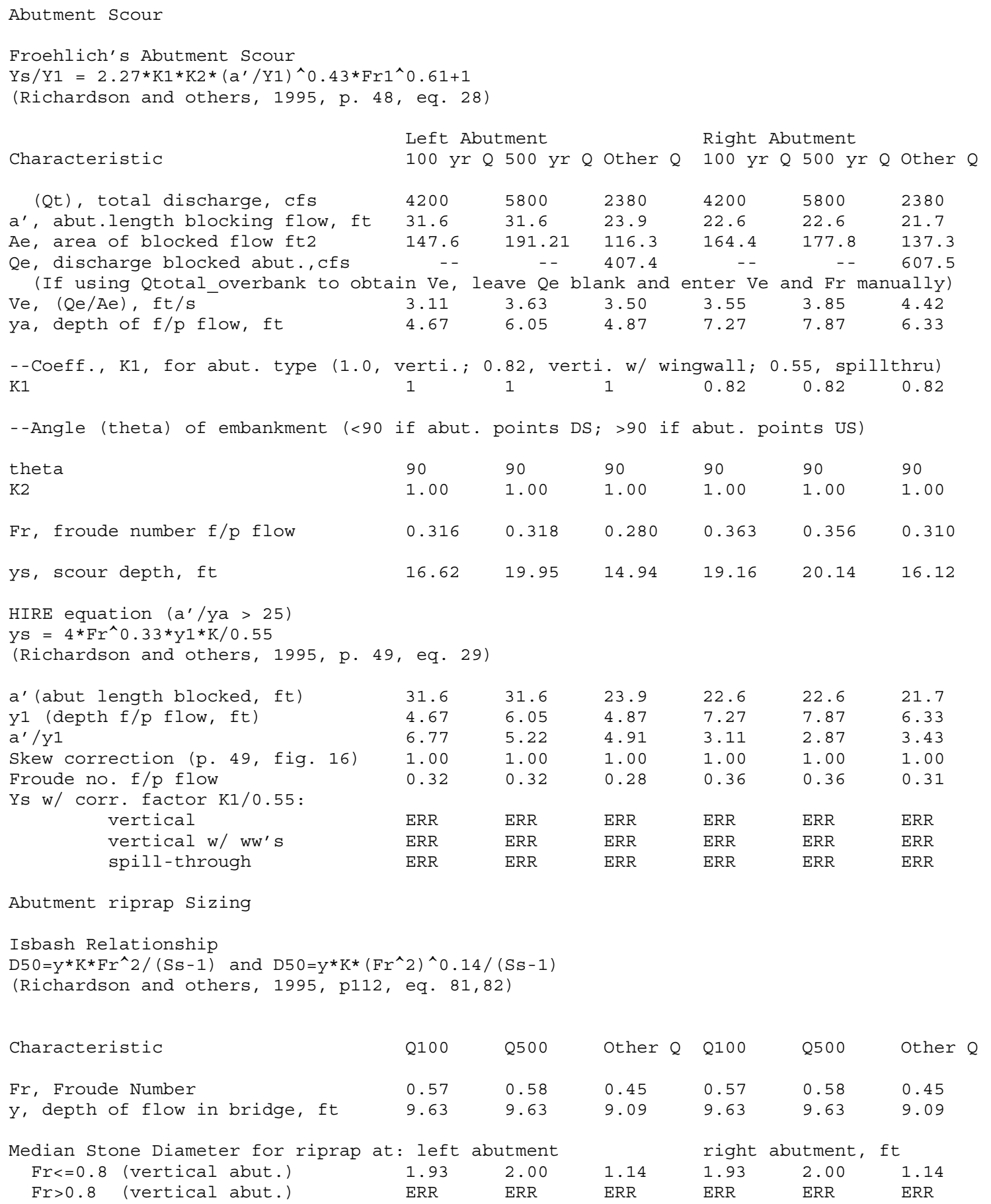


